\title{
Evaluation of climate model aerosol seasonal and spatial variability over Africa using AERONET
}

\author{
Hannah M. Horowitz ${ }^{1}$, Rebecca M. Garland ${ }^{2,3}$, Marcus Thatcher ${ }^{4}$, Willem A. Landman ${ }^{2,5}$, Zane Dedekind ${ }^{2}$, \\ Jacobus van der Merwe ${ }^{2}$, and Francois A. Engelbrecht ${ }^{2,6}$ \\ ${ }^{1}$ Department of Earth \& Planetary Sciences, Harvard University, Cambridge, MA 02138, USA \\ ${ }^{2}$ Natural Resources and the Environment Unit, Council for Scientific and Industrial Research, Pretoria 0001, South Africa \\ ${ }^{3}$ Climatology Research Group, North West University, Potchefstroom 2520, South Africa \\ ${ }^{4}$ Marine and Atmospheric Research, Commonwealth Scientific and Industrial Research Organisation, \\ Melbourne 3195, Australia \\ ${ }^{5}$ Department of Geography, Geoinformatics and Meteorology, University of Pretoria, Hatfield 0028, South Africa \\ ${ }^{6}$ School of Geography, Archaeology and Environmental Studies, University of the Witwatersrand, \\ Johannesburg 2000, South Africa
}

Correspondence to: Hannah M. Horowitz (hmhorow@post.harvard.edu)

Received: 17 March 2017 - Discussion started: 11 May 2017

Revised: 23 September 2017 - Accepted: 28 September 2017 - Published: 24 November 2017

\begin{abstract}
The sensitivity of climate models to the characterization of African aerosol particles is poorly understood. Africa is a major source of dust and biomass burning aerosols and this represents an important research gap in understanding the impact of aerosols on radiative forcing of the climate system. Here we evaluate the current representation of aerosol particles in the Conformal Cubic Atmospheric Model (CCAM) with ground-based remote retrievals across Africa, and additionally provide an analysis of observed aerosol optical depth at $550 \mathrm{~nm}\left(\mathrm{AOD}_{550 \mathrm{~nm}}\right)$ and Ångström exponent data from 34 Aerosol Robotic Network (AERONET) sites. Analysis of the 34 long-term AERONET sites confirms the importance of dust and biomass burning emissions to the seasonal cycle and magnitude of $\mathrm{AOD}_{550 \mathrm{~nm}}$ across the continent and the transport of these emissions to regions outside of the continent. In general, CCAM captures the seasonality of the AERONET data across the continent. The magnitude of modeled and observed multiyear monthly average $\mathrm{AOD}_{550 \mathrm{~nm}}$ overlap within \pm 1 standard deviation of each other for at least 7 months at all sites except the Réunion St Denis Island site (Réunion St. Denis). The timing of modeled peak $\mathrm{AOD}_{550 \mathrm{~nm}}$ in southern Africa occurs 1 month prior to the observed peak, which does not align with the timing of maximum fire counts in the region. For the western and northern African sites, it is evident that CCAM currently
\end{abstract}

overestimates dust in some regions while others (e.g., the Arabian Peninsula) are better characterized. This may be due to overestimated dust lifetime, or that the characterization of the soil for these areas needs to be updated with local information. The CCAM simulated $\mathrm{AOD}_{550 \mathrm{~nm}}$ for the global domain is within the spread of previously published results from CMIP5 and AeroCom experiments for black carbon, organic carbon, and sulfate aerosols. The model's performance provides confidence for using the model to estimate largescale regional impacts of African aerosols on radiative forcing, but local feedbacks between dust aerosols and climate over northern Africa and the Mediterranean may be overestimated.

\section{Introduction}

Africa contains the largest individual sources of biomass burning emissions and dust globally (Crutzen and Andreae, 1990; van der Werf et al., 2010; Schütz et al., 1981; Prospero et al., 2002). Dust aerosols and carbonaceous aerosols produced from biomass burning are known to impact climate through direct scattering and absorption of radiation, and indirectly through their effects on cloud formation and properties. Black carbon is estimated to be second only to $\mathrm{CO}_{2}$ 
in contributing to warming globally (Bond et al., 2013). Currently, the largest uncertainty in climate models is the impact of aerosols on the radiative balance of the Earth (Boucher et al., 2013).

Mineral dust emitted into the atmosphere primarily originates in topographic depressions (Prospero et al., 2002), consistent with the acceleration of winds in between mountains and plateaus (Evan et al., 2016). Meteorology plays a key role in the seasonality of dust emissions and transport in Africa. Latitudinal changes in the large-scale circulation, including the Intertropical Convergence Zone (ITCZ) and the African monsoon, shift the location of maximum dust activity and transport of dust northward $\left(\sim 5\right.$ to $\left.\sim 20^{\circ} \mathrm{N}\right)$ from winter through summer (Jankowiak and Tanre, 1992; Moulin et al., 1997; Prospero et al., 2002; Schepanski et al., 2009; Léon et al., 2009). The movement of the ITCZ also determines the seasonality of precipitation, and so determines the onset and severity of dry season biomass burning in Africa. Most fires in Africa are set by humans during the dry season for agricultural practices, when there is a near absence of convection and lightning (e.g., Swap et al., 2003; Archibald, 2016). Maximum biomass burning activity thus shifts from June-September in southern Africa to December-February in sub-Sahelian northern Africa (Haywood et al., 2008; Duncan et al., 2003; Cooke et al., 1996). The magnitude of emissions in a given biomass burning season is largely determined by the amount of rainfall preceding burning (which is affected by climate variability including the El Niño-Southern Oscillation), as this impacts the amount of vegetation that grows and can be burned (Swap et al., 2003; Anyamba et al., 2003; van der Werf et al., 2004). Biomass burning emissions in southern Africa contribute an estimated $86 \%$ of total carbonaceous aerosols emitted in Africa, which is a higher percentage than other regions worldwide (Bond et al., 2004). In many places, biomass burning aerosols dominate the seasonal cycle of the aerosol column in the region (Tesfaye et al., 2011; Queface et al., 2011; Sivakumar et al., 2010; Eck et al., 2003), which in turn can have a significant impact on the regional climate (Abel et al., 2005; Winkler et al., 2008; Tummon et al., 2010). Although these two sources dominate total column aerosol in Africa, fine anthropogenic aerosols are also observed, including at sites in the Sahara desert and off the coast of northern Africa (Rodríguez et al., 2011; Guirado et al., 2014).

In addition to the local and regional effects of African dust and biomass burning aerosols near emission sources, these aerosol particles can also be transported long distances to impact other regions. Saharan dust is exported over the Atlantic Ocean, cooling the tropical North Atlantic and influencing Atlantic climate variability (Evan et al., 2011; Doherty and Evan, 2014). Climate change may reduce future dust emissions, thus leading to a positive warming feedback over the North Atlantic (Evan et al., 2016). Saharan dust significantly enhances nutrient transport to regions like the Amazon rainforest, which may also have a feedback on climate (e.g.,
Bristow et al., 2010; Yu et al., 2015). Over southern Africa, massive aerosol plumes during peak biomass burning are exported in a so-called "river of smoke" off the southeastern coast of southern Africa to the Indian Ocean, as well as over the southwestern coast over Angola out to the Atlantic Ocean (Garstang et al., 1996; Tyson et al., 1996a, b; Swap et al., 2003). This latter exit pathway aligns with the stratocumulus cloud deck that forms off of the southwestern coast and has motivated multiple recent and ongoing ground-based and aircraft campaigns (Zuidema et al., 2016). The simulation of this cloud deck with the AeroCom intercomparison of global models was found to differ significantly between models, and to be the area of highest uncertainty in modeling aerosol radiative forcing (Stier et al., 2013). An assessment of the first phase of AeroCom showed that the largest model differences were from dust and carbonaceous aerosols (Kinne et al., 2006), the dominant aerosol constituents over Africa. Additionally, this AeroCom experiment highlighted an overestimation of dust at northern African sites in winter (Kinne et al., 2006). An accurate representation of African aerosols is critical in climate models to understand the regional and global radiative forcing and climate impacts of dust and biomass burning aerosols, at present and under future climate change, and is currently a major challenge.

This study performs the first evaluation of the representation of African aerosols in the Conformal Cubic Atmospheric Model (CCAM) (McGregor, 2005). The CCAM aerosol parameterizations are based on the CSIRO Mk3.6 climate model used in the Fifth Coupled Model Intercomparison Project (CMIP5) to estimate radiative forcing for the Intergovernmental Panel on Climate Change AR5. CCAM will be included as part of a coupled earth system model, the Variable Resolution Earth System Model (VRESM), in the South African Council of Scientific and Industrial Research (CSIR) submission to CMIP6. We evaluate CCAM using the CMIP5 emissions inventory against long-term aerosol optical depth (AOD) retrievals across Africa and outflow regions off the coast from the Aerosol Robotic Network (AERONET) (Holben et al., 1998). A particular emphasis is placed on evaluating the long-term seasonal variability at sites heavily impacted by dust and biomass burning aerosol particles. CCAM simulates four prognostic aerosol species (organic carbon (OC), black carbon (BC), sulfate, and dust) and diagnostic (i.e., prescribed) sea salt aerosols, as well as their individual contributions to total AOD. Detailed case studies at six sites across Africa are used to examine the modeled source distribution of AOD and to understand the model processes, determining how well CCAM represents the observational data. The evaluation of aerosols in CCAM against observations has implications for its estimates of radiative forcing. 


\section{Methods}

\subsection{CCAM model description}

CCAM is a global atmospheric circulation model, and was run at a quasi-uniform resolution of $50 \mathrm{~km}$ in the horizontal and with 27 levels in the vertical. The simulations applied in this study form part of the CSIR's contribution to the Coordinated Regional Downscaling Experiment (CORDEX) of the World Climate Research Programme (WCRP). Horizontal wind and temperature upwards of $900 \mathrm{hPa}$ and the surface pressure in CCAM were nudged towards the ERA-Interim reanalysis data (Dee et al., 2011). This nudging was applied every $6 \mathrm{~h}$ at a length scale of $\sim 2250 \mathrm{~km}$ using the digital filter of Thatcher and McGregor (2009). The sea-surface temperature and sea-ice data from ERA-Interim were used as lower boundary forcing; these values were interpolated to the CCAM grid with the differences in the land-sea mask taken into account. For this study, 6-hourly model output was regridded to $0.5^{\circ} \times 0.5^{\circ}$ resolution over the African continent $\left(40^{\circ} \mathrm{N}\right.$ to $40^{\circ} \mathrm{S}, 20^{\circ} \mathrm{W}$ to $60^{\circ} \mathrm{E}$ ) from 1999 to 2012 , the period for which most AERONET observations are available for comparison. The simulation was initialized in 1979 such that prognostic soil variables like temperature and moisture, in addition to aerosol fields, were sufficiently spun up.

The aerosol parameterization in CCAM has been documented in detail elsewhere (Rotstayn et al., 2007, 2010, 2011, 2012). In summary, the aerosol scheme is a bulk mass scheme (i.e., single moment) to represent the sulfur cycle, carbonaceous aerosols, dust, and diagnosed sea salt. Carbonaceous aerosols are represented by separate prognostic species for OC and BC. Sea salt concentrations above the ocean surface are diagnosed (i.e., prescribed) at each time step as a function of the $10 \mathrm{~m}$ wind speed. It is assumed that sea salt aerosols are well mixed in the marine boundary layer (MBL), and that the concentration is zero above the MBL. There are two size bins of sea salt aerosols (mode radii of 0.035 and $0.35 \mu \mathrm{m}$ ). As the sea salt concentrations are prescribed at each time step, they are not actively emitted, transported, or removed, and thus no sea salt is transported over land (Rotstayn et al., 2007).

The atmospheric model determines the transport of the prognostic aerosol species (sulfate, carbonaceous, and dust aerosols), including turbulent mixing in the boundary layer and transport due to convection. Wet scavenging processes are included, with links to warm rain and frozen precipitation processes in the cloud microphysics parameterizations and the convection scheme (Rotstayn et al., 2007). The model also accounts for both direct and indirect aerosol effects, representing an important feedback into the atmospheric simulation. The semidirect effect is also included in CCAM; however, as the vertical temperatures upwards of $900 \mathrm{hPa}$ are nudged towards the ERA-Interim reanalysis data every $6 \mathrm{~h}$ in accordance with CORDEX, the semidirect impact on the simulation presented here is diminished.
The size distribution of the sulfate, $\mathrm{OC}$, and $\mathrm{BC}$ aerosol particles is represented by a mode radius with a geometric standard deviation. Dust is represented by four size bins with radii of $0.1-1,1-2,2-3$, and $3-6 \mu \mathrm{m}$, with the parameterization of eolian dust emissions closely based on Ginoux et al. (2001, 2004) (see also Rotstayn et al., 2011). Specifically, dust emissions are described by the expression

$F_{\mathrm{p}}=C \operatorname{Cs}_{\mathrm{p}} u_{10 \mathrm{~m}}^{2}\left(u_{10 \mathrm{~m}}-u_{\mathrm{t}}\right)$ (if, $\left.u_{10 \mathrm{~m}}>u_{\mathrm{t}}\right)$,

where $F_{\mathrm{p}}$ is the flux $\left(\mu \mathrm{g} \mathrm{s}^{-1} \mathrm{~m}^{-2}\right), C$ is a dimensional factor set to $0.5 \mu \mathrm{g} \mathrm{s}^{2} \mathrm{~m}^{-5}, S s_{\mathrm{p}}$ is a fraction for each dust size bin following Ginoux et al. (2001), $u_{10 \mathrm{~m}}$ is the horizontal wind speed $\left(\mathrm{m} \mathrm{s}^{-1}\right)$, and $u_{\mathrm{t}}\left(\mathrm{m} \mathrm{s}^{-1}\right)$ is the threshold velocity, which accounts for soil moisture and the particle size. If $u_{10 \mathrm{~m}}$ is not greater than $u_{\mathrm{t}}$, then $F_{\mathrm{p}}=0$. For this study, the dimensional factor $C$ was set to be smaller than that used by Ginoux et al. (2001), which has the effect of reducing the dust emissions for the same wind speed and soil moisture.

Emissions of $\mathrm{OC}, \mathrm{BC}$, and $\mathrm{SO}_{2}$ from anthropogenic and biomass burning sources are from the CMIP5 recommended historical emissions datasets through the year 2000 (Lamarque et al., 2010) and extend through 2012 using emissions from the RCP4.5 modest mitigation scenario (Moss et al., 2010; Riahi et al., 2007). Aerosol emissions across the RCP scenarios through the latest year simulated here (2012) are similar (van Vuuren et al., 2011). Within CCAM, of the $\mathrm{SO}_{2}$ emissions from fossil fuel and smelting, $3 \%$ are emitted as sulfate directly (Rotstayn and Lohmann, 2002); a similar fraction is assumed in other global models to represent rapid in-plume transformation of $\mathrm{SO}_{2}$ to sulfate (Liu et al., 2005; Chin et al., 2000; Koch et al., 1999). The model has three prognostic variables to represent the sulfur cycle: dimethyl sulfide (DMS), $\mathrm{SO}_{2}$, and sulfate. Additional minor sources of model sulfate aerosol are volcanic $\mathrm{SO}_{2}$ emissions and biogenic DMS emissions, which can be oxidized to sulfate (Rotstayn and Lohmann, 2002). Concentrations of sulfur oxidants $\left(\mathrm{OH}, \mathrm{NO}_{3}, \mathrm{H}_{2} \mathrm{O}_{2}\right.$, and $\left.\mathrm{O}_{3}\right)$ are prescribed, with the amount of $\mathrm{SO}_{2}$ dissolved into cloud water described by Henry's Law.

Within the CMIP5 emissions used, anthropogenic and biomass burning sources vary decadally, and during the 2005-2012 period forced by RCP4.5 they vary every 5 years. Biomass burning emissions also have a monthly varying annual cycle, while non-biomass burning anthropogenic emissions remain constant annually. Thus, changes in modeled aerosol loading using the CMIP5 emissions on smaller than monthly temporal scales for $\mathrm{OC}, \mathrm{BC}$, and sulfate, as well as interannual variability within a given decade, are not due to changes in sources, but instead changes in transport and deposition sinks resulting from meteorological variability. An earlier study over southern Africa during the biomass burning season found that a chemical transport model was able to reproduce day-to-day variability in AOD using timeinvariant emissions, suggesting meteorological variability is more important on this timescale than emissions (Myhre et al., 2003). 
Prognostic aerosol species for hydrophobic and hydrophilic forms of $\mathrm{OC}$ and $\mathrm{BC}$ are transported separately in CCAM. Hydrophobic OC and BC are non-hygroscopic, while hydrophilic species' hygroscopic growth is based on Köhler theory. The model assumes fossil fuel emissions are $50 \%$ hydrophilic, and biomass and biofuel burning are $100 \%$ hydrophilic. Conversion from hydrophobic to hydrophilic follows Cooke et al. (1999) with an $e$-folding lifetime of 1.15 days. Secondary organic aerosol (SOA) formation is not treated in the model. All prognostic aerosol species are removed via wet and dry deposition, while dust is additionally removed through gravitational settling (Rotstayn and Lohmann, 2002; Lohmann et al., 1999; Ginoux et al., 2001).

\subsection{AERONET observational data}

The global network of AERONET stations measure aerosol optical properties at multiple wavelengths ranging from the UV to shortwave infrared using a ground-based Cimel sun photometer (Holben et al., 1998). For this work, the retrieved $\mathrm{AOD}$ at $440 \mathrm{~nm}\left(\mathrm{AOD}_{440 \mathrm{~nm}}\right)$ and the Ångström exponent of extinction for 440 to $870 \mathrm{~nm}\left(\alpha_{\text {ext(440/870) }}\right)$ from AERONET were used.

The Ångström exponent of extinction is the negative slope of the natural $\log$ of AOD with wavelength. The $\mathrm{AOD}_{440 \mathrm{~nm}}$ was adjusted to $550 \mathrm{~nm}$ using the $\alpha_{\mathrm{ext}(440 / 870)}$ for comparison to modeled AOD at $550 \mathrm{~nm}$ following Eq. (2), where $\tau_{440}$ is $\mathrm{AOD}$ at $440 \mathrm{~nm}$ retrieved by AERONET, and $\tau_{550}$ is AOD at $550 \mathrm{~nm}$ :

$\tau_{550}=\tau_{440}\left(\frac{550}{440}\right)^{-\alpha_{\operatorname{ext}(440 / 870)}}$.

A climatology of $\mathrm{AOD}_{550 \mathrm{~nm}}$ and $\alpha_{\mathrm{ext}(440 / 870)}$ observations from 34 sites in Africa and the Middle East outside of heavily urbanized areas with at least 1 full year of level 2.0 data (cloud-screened and manually inspected for quality assurance, Smirnov et al., 2000; see Fig. 1 and Tables 1 and 2) is developed. Sites were selected in southern Africa that could characterize the model performance in regions dominated by biomass burning aerosol, and in northern and western Africa and the Middle East, sites that could characterize the model representation of Saharan and Sahelian dust sources and outflow were selected. This analysis includes sites in the Mediterranean and Europe influenced by northern African dust outflow (Basart et al., 2009; Toledano et al., 2007a, b; Querol et al., 2009; Pace et al., 2006).

For the comparison with model outputs, sites with multiple years of complete data for most of the annual cycle (see Sect. 2.3 and Fig. 3a and b) were selected. Where multiple sites were proximal to each other and showed similar features, the site with the longest data record was selected to be representative of the sites and was used for comparison to the model (see site names in bold font in Fig. 1, and Tables 1 and 2). This selection results in 23 sites being chosen and used in the comparison with model outputs. Daily average values, calculated for days with at least three measurements, were downloaded from the AERONET website (http://aeronet.gsfc.nasa.gov) and used in this analysis.

\subsection{Model-observation comparisons}

Monthly-average time series and multiyear monthly mean climatology of $\mathrm{AOD}_{550 \mathrm{~nm}}$ were calculated for each site for observed and modeled data. The $550 \mathrm{~nm}$ wavelength is representative of the model AOD output. The modeled Ångstrom exponent is not available. The AERONET monthly average $\mathrm{AOD}_{550 \mathrm{~nm}}$ was calculated from the daily averages using a $70 \%$ data completeness rule (i.e., if more than $30 \%$ of the daily values were missing, a monthly average was not calculated for that time period). A multiyear mean seasonal cycle was also calculated from daily averages for each month for all available years of data at each site, following the same data coverage exclusions. This is to ensure that the observed monthly averages were representative of the entire month to provide a relevant comparison for modeled output, as it is difficult for climate models to represent specific days individually (e.g., Magi et al., 2009), and as CCAM used CMIP5 emissions that do not vary daily.

Daily average AOD from AERONET is calculated for a minimum of three time points from sun photometer measurements, which can only be made during daytime, while modeled AOD is reported at 6-hourly resolution. Therefore, only CCAM AOD between 06:00 and 18:00 UTC was averaged for monthly and multiyear means (similar to other AERONET-model comparison studies, e.g., Tegen et al., 2013). Model monthly means were, however, insensitive to the choice of daylight cut-off (see Fig. 2), which gives confidence that the instantaneous 6-hourly values from CCAM can represent the range of daytime hours sampled by AERONET. Multiyear CCAM seasonal cycles were calculated from daily averages at each site from (1) only the specific months with valid observational data and (2) all months of all model years (1999-2012). As many of the observational sites do not have continuous data, nor are the sampling times across sites always overlapping, the two calculations of modeled multiyear seasonal cycles were compared to test whether the entire model time period (1999-2012) for each month could be used to evaluate modeled spatial patterns against all available sites (Sect. 4.2.5).

Modeled and observed AOD $_{550 \mathrm{~nm}}$ at each site were compared on a monthly timescale using a variety of metrics to quantify how well the model captures seasonal and interannual variability, as well as overall magnitude. To this end, the Pearson's correlation coefficient between the model and observations $(r)$, normalized mean bias (NMB) of the model as a percentage of the observed values, and the mean absolute error (MAE) of the model in units of $\mathrm{AOD}_{550 \mathrm{~nm}}$ were calculated.

We also compare modeled daily average $\mathrm{AOD}_{550 \mathrm{~nm}}$, using the same daylight hours previously described, to observed 


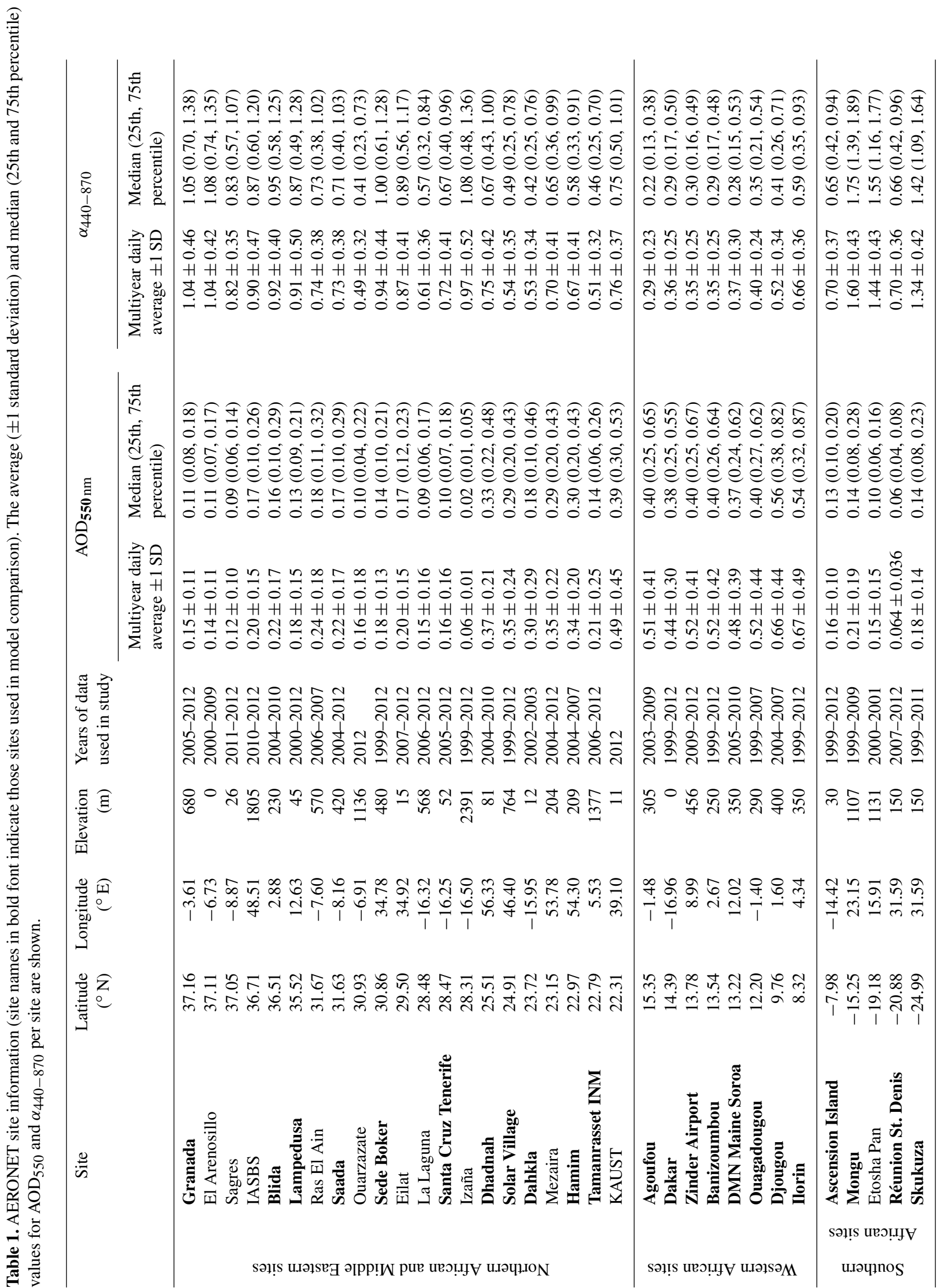




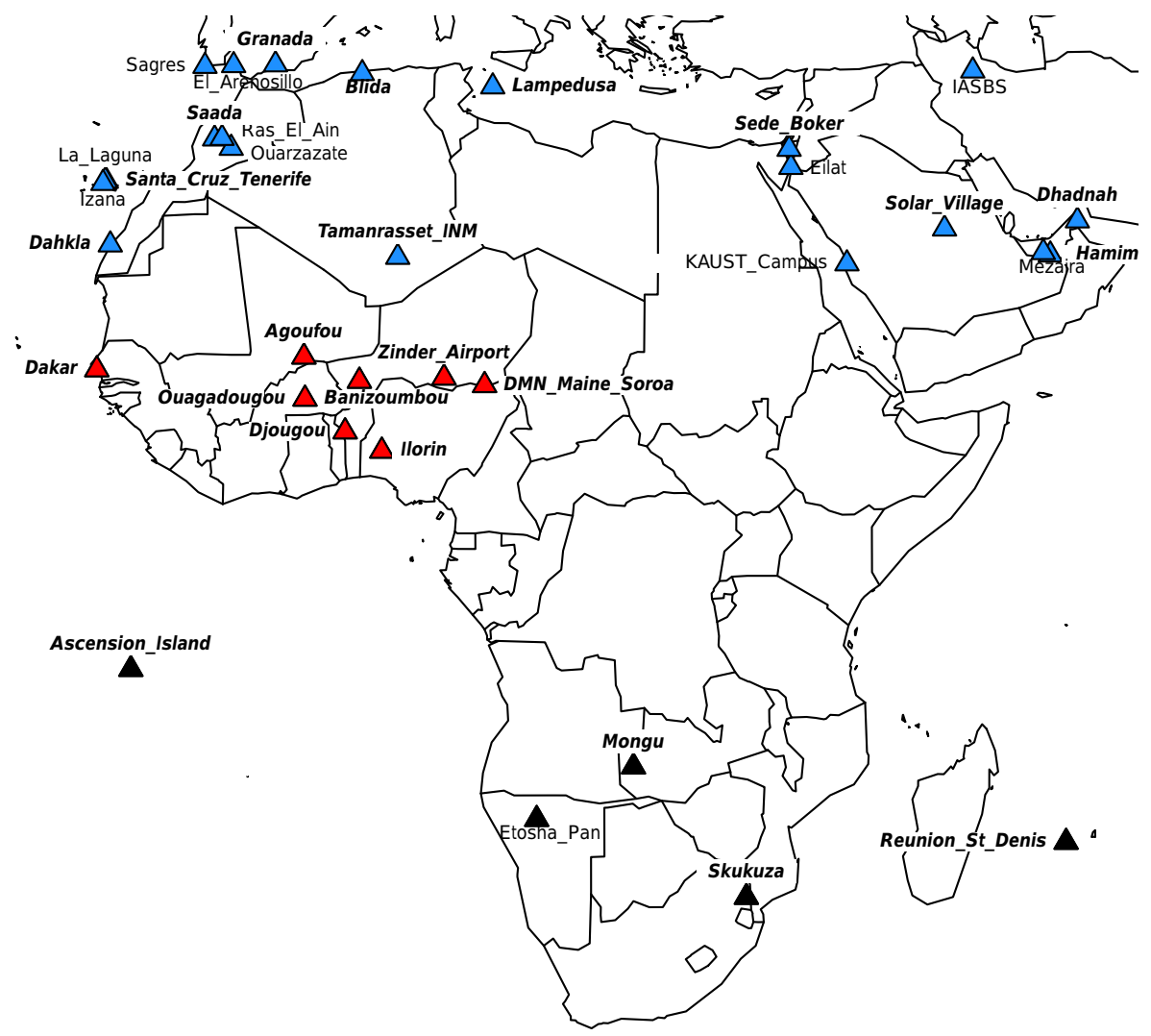

Figure 1. Map of long-term AERONET sites used in this study. Sites are color-coded by general geographic area and aerosol source type. Site names in bold italics are used in the model comparison.

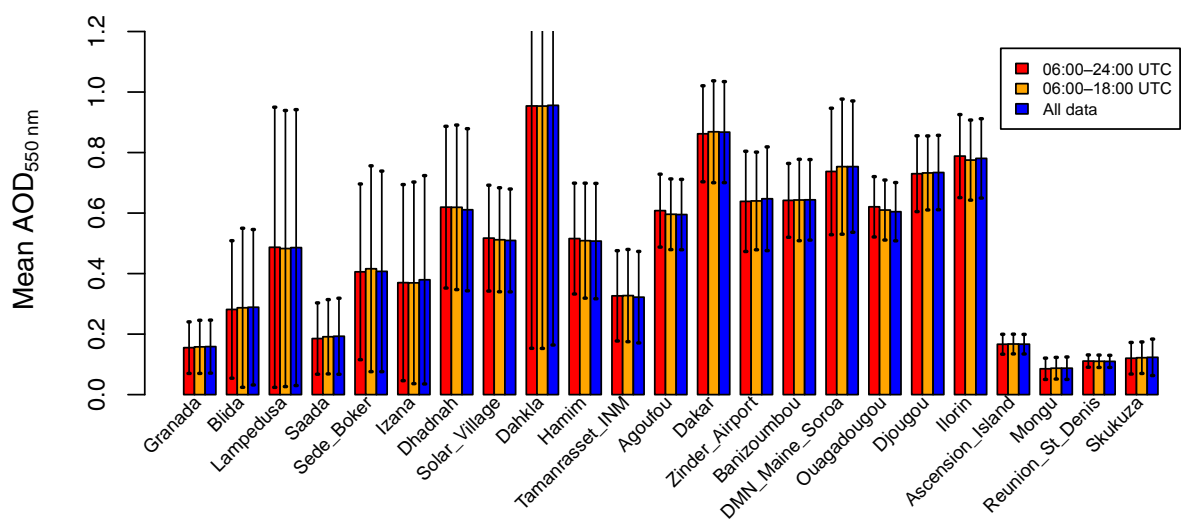

Figure 2. Comparison of methods to compute mean modeled $\mathrm{AOD}_{550 \mathrm{~nm}}$, for an example in January 2000: red bars include model output only for 06:00 to 24:00 UTC; yellow bars for 06:00 to 18:00 UTC; and blue bars for $24 \mathrm{~h}$. Whiskers are \pm 1 standard deviation across the 6-hourly model values within each time range.

AERONET daily average $\mathrm{AOD}_{550 \mathrm{~nm}}$ for the specific days with available data at each site. As described in Sect. 2.1, outside of the dust parameterization, the experimental setup of the model following CMIP5 does not take daily variations in emissions into account, and thus the daily variation in modeled AOD from all other aerosol types will be due to daily variations in transport and removal only. Even with these limitations, the daily comparison is useful for further investigating model biases. 


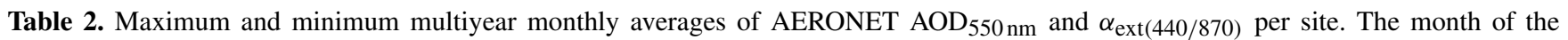
reported maximum or minimum value is indicated in parenthesis. Site names in bold font are used in model comparison.

\begin{tabular}{|c|c|c|c|c|c|c|}
\hline & & \multirow[t]{2}{*}{ Site } & \multicolumn{2}{|c|}{$\mathrm{AOD}_{550 \mathrm{~nm}}$} & \multicolumn{2}{|c|}{$\alpha_{440-870}$} \\
\hline & & & $\begin{array}{l}\text { Max multiyear monthly } \\
\text { average } \pm 1 \text { SD (month) }\end{array}$ & $\begin{array}{l}\text { Min multiyear monthly } \\
\text { average } \pm 1 \text { SD (month) }\end{array}$ & $\begin{array}{l}\text { Max multiyear monthly } \\
\text { average } \pm 1 \text { SD (month) }\end{array}$ & $\begin{array}{l}\text { Min multiyear monthly } \\
\text { average } \pm 1 \text { SD (month) }\end{array}$ \\
\hline \multirow{21}{*}{ 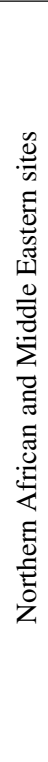 } & & Granada & $0.19 \pm 0.13(\mathrm{Aug})$ & $0.083 \pm 0.041(\mathrm{Jan})$ & $1.59 \pm 0.26(\mathrm{Jan})$ & $0.67 \pm 0.36(\mathrm{Aug})$ \\
\hline & & El Arenosillo & $0.17 \pm 0.13(\mathrm{Sep})$ & $0.088 \pm 0.052(\mathrm{Dec})$ & $1.38 \pm 0.43(\mathrm{Jan})$ & $0.96 \pm 0.41($ Apr $)$ \\
\hline & & Sagres & $0.17 \pm 0.23(\mathrm{Jun})$ & $0.080 \pm 0.036(\mathrm{Jan})$ & $1.07 \pm 0.19(\mathrm{Feb})$ & $0.68 \pm 0.24$ (Mar) \\
\hline & & IASBS & $0.30 \pm 0.22$ (May) & $0.081 \pm 0.036(\mathrm{Dec})$ & $1.59 \pm 0.27(\mathrm{Dec})$ & $0.41 \pm 0.21(\mathrm{Jun})$ \\
\hline & & Blida & $0.36 \pm 0.18(\mathrm{Jul})$ & $0.11 \pm 0.07(\mathrm{Nov})$ & $1.10 \pm 0.37(\mathrm{Jan})$ & $0.72 \pm 0.38(\mathrm{Jul})$ \\
\hline & & Lampedusa & $0.24 \pm 0.14(\mathrm{Jul})$ & $0.085 \pm 0.050(\mathrm{Dec})$ & $1.08 \pm 0.54(\mathrm{Aug})$ & $0.55 \pm 0.28(\mathrm{Dec})$ \\
\hline & & Ras El Ain & $0.46 \pm 0.22(\mathrm{Jul})$ & $0.090 \pm 0.052(\mathrm{Feb})$ & $1.15 \pm 0.36($ Apr $)$ & $0.35 \pm 0.19(\mathrm{Jul})$ \\
\hline & & Saada & $0.39 \pm 0.23(\mathrm{Jul})$ & $0.087 \pm 0.050(\mathrm{Jan})$ & $1.00 \pm 0.38(\mathrm{Dec})$ & $0.48 \pm 0.27(\mathrm{Jul})$ \\
\hline & & Ouarzazate & $0.38 \pm 0.22(\mathrm{Aug})$ & $0.033 \pm 0.016(\mathrm{Dec})$ & $0.96 \pm 0.26(\mathrm{Dec})$ & $0.17 \pm 0.11(\mathrm{Jul})$ \\
\hline & & Sede Boker & $0.26 \pm 0.17(\mathrm{Apr})$ & $0.11 \pm 0.08(\mathrm{Dec})$ & $1.18 \pm 0.29(\mathrm{Aug})$ & $0.57 \pm 0.40(\mathrm{Apr})$ \\
\hline & & Eilat & $0.29 \pm 0.21(\mathrm{Apr})$ & $0.11 \pm 0.04(\mathrm{Jan})$ & $1.20 \pm 0.36(\mathrm{Jul})$ & $0.56 \pm 0.38(\mathrm{Apr})$ \\
\hline & & La Laguna & $0.28 \pm 0.21(\mathrm{Jul})$ & $0.055 \pm 0.021(\mathrm{Dec})$ & $0.95 \pm 0.46(\mathrm{Dec})$ & $0.37 \pm 0.24(\mathrm{Aug})$ \\
\hline & & Santa Cruz Tenerife & $0.26 \pm 0.20(\mathrm{Jul})$ & $0.065 \pm 0.028(\mathrm{Dec})$ & $0.90 \pm 0.52($ Apr $)$ & $0.54 \pm 0.45(\mathrm{Jul})$ \\
\hline & & Izaña & $0.15 \pm 0.16(\mathrm{Jul})$ & $0.015 \pm 0.007(\mathrm{Feb})$ & $1.34 \pm 0.37(\mathrm{Dec})$ & $0.54 \pm 0.50(\mathrm{Aug})$ \\
\hline & & Dhadnah & $0.69 \pm 0.20(\mathrm{Jul})$ & $0.19 \pm 0.10($ Jan $)$ & $1.20 \pm 0.42(\mathrm{Dec})$ & $0.44 \pm 0.21(\mathrm{Apr})$ \\
\hline & & Solar Village & $0.55 \pm 0.32$ (May) & $0.17 \pm 0.14(\mathrm{Jan})$ & $0.83 \pm 0.36(\mathrm{Dec})$ & $0.22 \pm 0.15$ (May) \\
\hline & & Dahkla & $0.62 \pm 0.34(\mathrm{Jul})$ & $0.12 \pm 0.05(\mathrm{Dec})$ & $0.73 \pm 0.36(\mathrm{Nov})$ & $0.30 \pm 0.20(\mathrm{Jul})$ \\
\hline & & Mezaira & $0.58 \pm 0.21$ (Jun) & $0.19 \pm 0.07(\mathrm{Dec})$ & $1.10 \pm 0.33(\mathrm{Nov})$ & $0.30 \pm 0.22$ (Mar) \\
\hline & & Hamim & $0.58 \pm 0.28$ (Jun) & $0.18 \pm 0.09(\mathrm{Jan})$ & $1.22 \pm 0.46(\mathrm{Dec})$ & $0.27 \pm 0.17$ (Jun) \\
\hline & & Tamanrasset INM & $0.39 \pm 0.35$ (Aug) & $0.056 \pm 0.045($ Jan $)$ & $0.80 \pm 0.32(\mathrm{Jan})$ & $0.20 \pm 0.14$ (Jun) \\
\hline & & KAUST & $0.67 \pm 0.81$ (Mar) & $0.36 \pm 0.19$ (Apr) & $1.24 \pm 0.28(\mathrm{Nov})$ & $0.40 \pm 0.17$ (May) \\
\hline \multirow{8}{*}{ 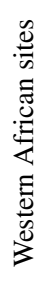 } & & Agoufou & $0.77 \pm 0.41($ Jun $)$ & $0.28 \pm 0.24(\mathrm{Dec})$ & $0.53 \pm 0.25(\mathrm{Dec})$ & $0.092 \pm 0.099$ (Jun) \\
\hline & & Dakar & $0.62 \pm 0.29$ (Jun) & $0.30 \pm 0.19$ (Nov) & $0.62 \pm 0.30(\mathrm{Dec})$ & $0.19 \pm 0.15($ Jun $)$ \\
\hline & & Zinder Airport & $0.89 \pm 0.56$ (May) & $0.32 \pm 0.28(\mathrm{Nov})$ & $0.51 \pm 0.29(\mathrm{Dec})$ & $0.14 \pm 0.11$ (May) \\
\hline & & Banizoumbou & $0.89 \pm 0.57$ (Mar) & $0.29 \pm 0.23(\mathrm{Dec})$ & $0.54 \pm 0.29(\mathrm{Dec})$ & $0.16 \pm 0.21($ Jun $)$ \\
\hline & & DMN Maine Soroa & $1.01 \pm 0.75$ (May) & $0.26 \pm 0.14(\mathrm{Dec})$ & $0.62 \pm 0.35(\mathrm{Dec})$ & $0.10 \pm 0.09$ (Jun) \\
\hline & & Ouagadougou & $0.88 \pm 0.70$ (Mar) & $0.33 \pm 0.28(\mathrm{Dec})$ & $0.56 \pm 0.26(\mathrm{Dec})$ & $0.24 \pm 0.11$ (Mar) \\
\hline & & Djougou & $0.97 \pm 0.48$ (Mar) & $0.35 \pm 0.14(\mathrm{Oct})$ & $0.96 \pm 0.30(\mathrm{Dec})$ & $0.27 \pm 0.12$ (Mar) \\
\hline & & Ilorin & $1.10 \pm 0.56(\mathrm{Feb})$ & $0.38 \pm 0.22($ Jun $)$ & $0.91 \pm 0.30(\mathrm{Dec})$ & $0.33 \pm 0.16($ Apr $)$ \\
\hline \multirow{5}{*}{ 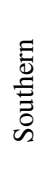 } & & Ascension Island & $0.32 \pm 0.14($ Sep $)$ & $0.086 \pm 0.037(\mathrm{Nov})$ & $1.34 \pm 0.17(\mathrm{Sep})$ & $0.280 \pm 0.147(\mathrm{Apr})$ \\
\hline & 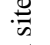 & Mongu & $0.50 \pm 0.26(\mathrm{Sep})$ & $0.080 \pm 0.040(\mathrm{Apr})$ & $1.85 \pm 0.16($ Aug $)$ & $0.812 \pm 0.363($ Jan $)$ \\
\hline & ฮี & Etosha Pan & $0.40 \pm 0.17$ (Oct) & $0.069 \pm 0.042$ (May) & $1.80 \pm 0.16(\mathrm{Oct})$ & $1.14 \pm 0.40(\mathrm{Nov})$ \\
\hline & $\stackrel{0}{\Xi}$ & Réunion St. Denis & $0.095 \pm 0.044(\mathrm{Oct})$ & $0.046 \pm 0.018(\mathrm{Jul})$ & $1.12 \pm 0.28(\mathrm{Oct})$ & $0.452 \pm 0.270(\mathrm{Jul})$ \\
\hline & $\ll$ & Skukuza & $0.27 \pm 0.18(\mathrm{Sep})$ & $0.13 \pm 0.09(\mathrm{Jul})$ & $1.46 \pm 0.28(\mathrm{Sep})$ & $0.996 \pm 0.473(\mathrm{Jan})$ \\
\hline
\end{tabular}

\section{Climatology of AERONET AOD and $\alpha_{\text {ext }}$ observations over Africa: seasonal variability and drivers}

AERONET and CCAM AOD are all reported at $550 \mathrm{~nm}$. Additionally, the Ångström exponent of extinction $\left(\alpha_{\text {ext }}\right)$ from AERONET reported here is from the 440 and $870 \mathrm{~nm}$ wavelength pair. Figure $3 a$ and $b$ show a compilation of multiyear monthly mean observed AOD and Fig. $4 \mathrm{a}$ and $\mathrm{b} \alpha_{\text {ext }}$ for the 34 study sites, ordered by region from north to south. The symbols are the multiyear mean values, and the whiskers represent \pm 1 standard deviation. The number of years of AERONET data used per month is shown at the top of each plot. The Ångström exponent is an empirical proxy related to the relative contribution to optical thickness from coarse vs. fine aerosols, with values varying between ap- proximately 0 for pure coarse dust particles to 2 for predominantly fine particles (Léon et al., 2009; Hamonou et al., 1999). In Fig. $4 a$ and b, values of $\alpha_{\text {ext }}$ below 0.4 are indicative of aerosols dominated by coarse particles (e.g., mineral dust or coarse sea salt particles) (shaded gray area), while higher values show a contribution from predominantly fine, submicron aerosols, indicative of biomass burning or anthropogenic sources (Holben et al., 2001; Ogunjobi et al., 2008; Rajot et al., 2008).

Table 1 displays the multiyear daily average and median AOD and $\alpha_{\text {ext }}$, which were calculated using all available data points per site. Table 2 displays the maximum and minimum multiyear monthly average per site together with the month when that value was observed. The amount of data is not equal at all sites, nor were the sampling periods at all sites overlapping, and thus detailed comparisons of the sites are 
(a)

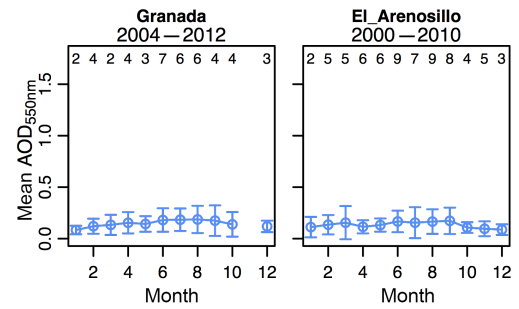

(a)

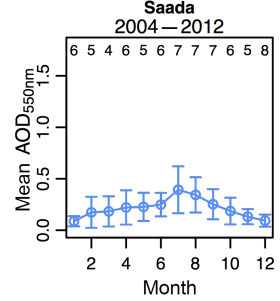

(a)

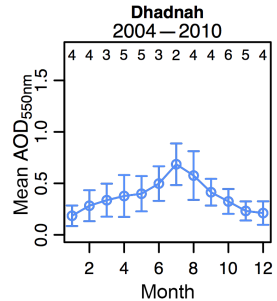

Ouarzazate
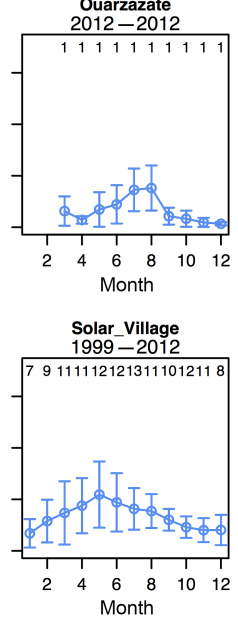
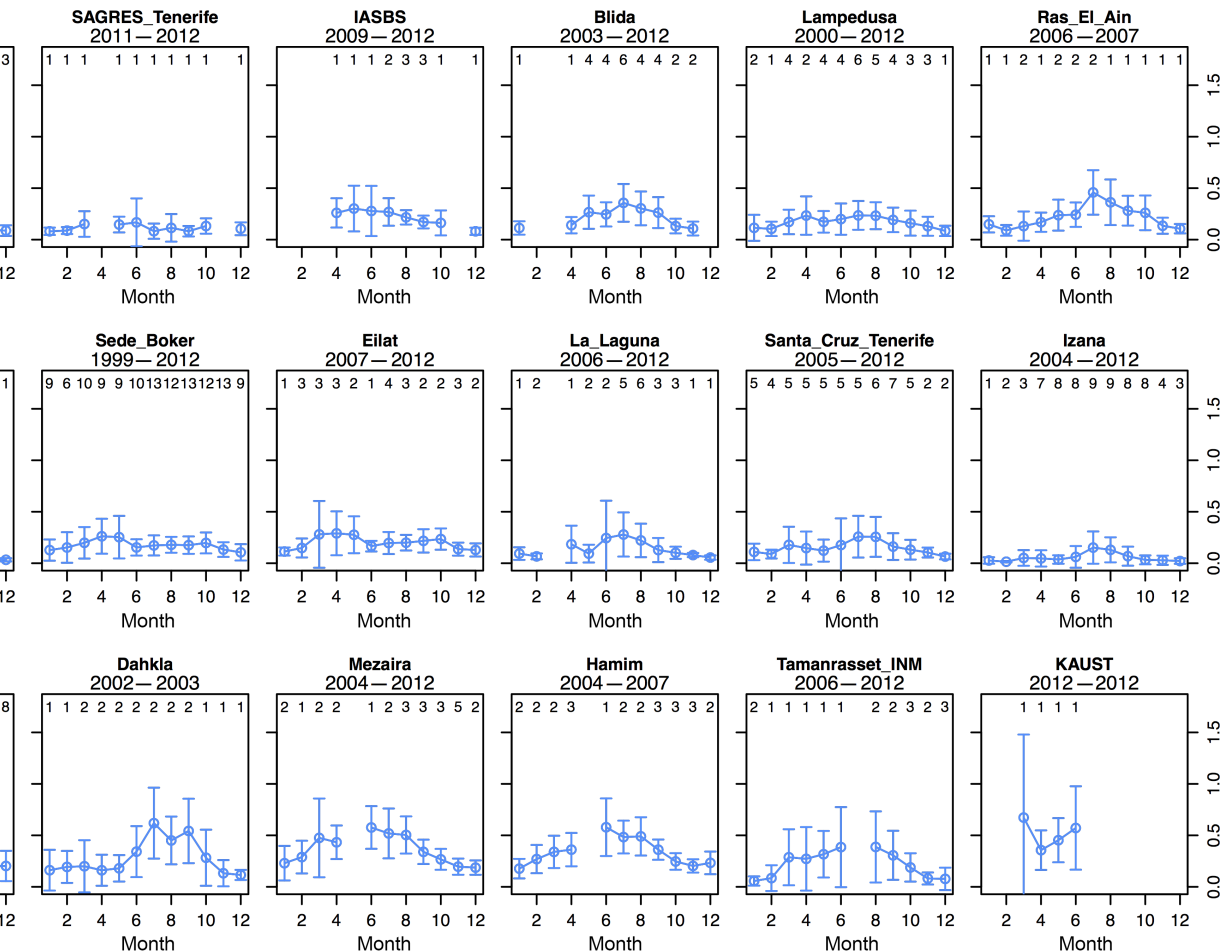

Month

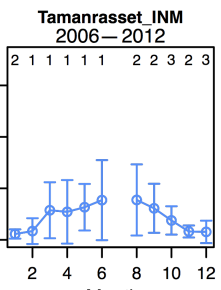

Month
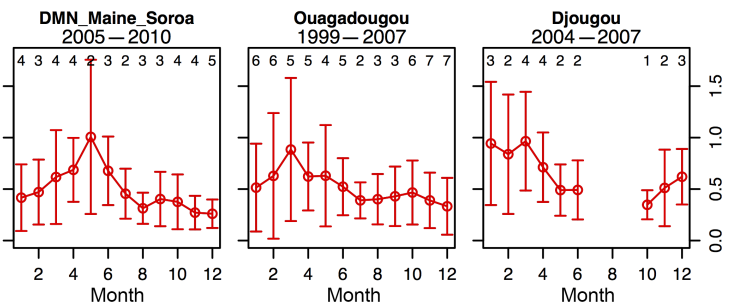

(b)
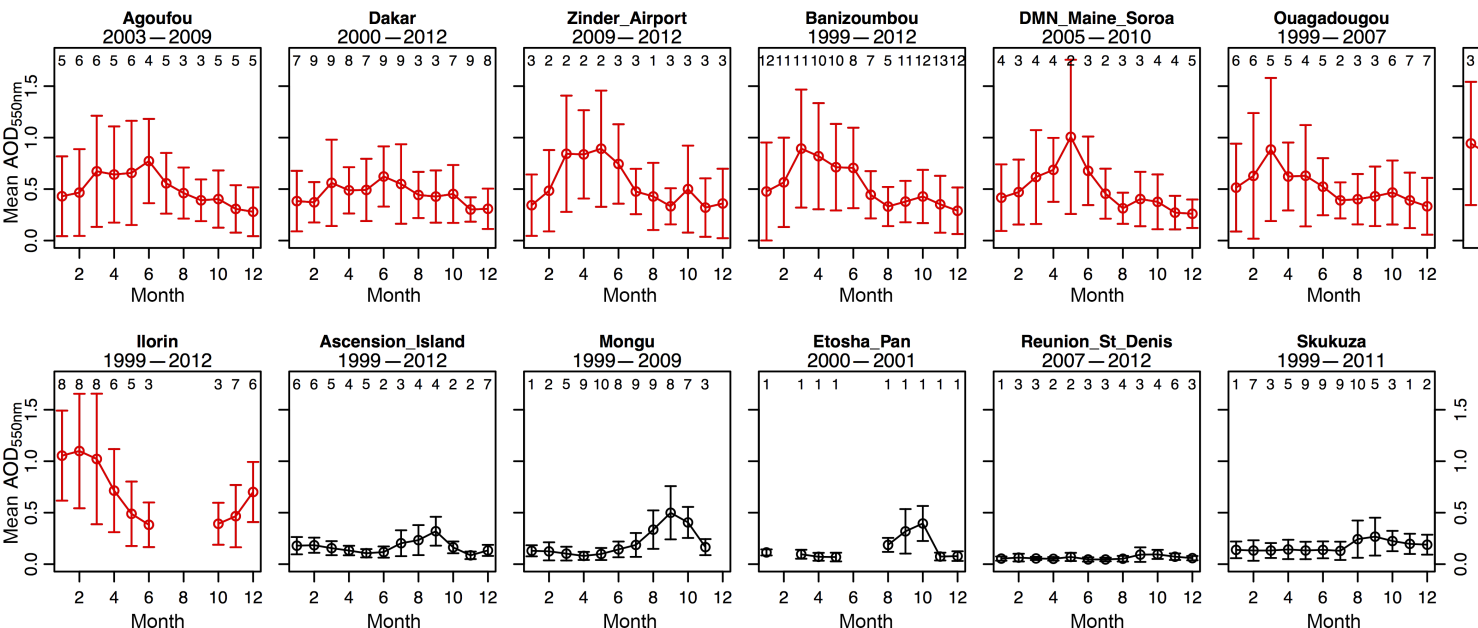

Figure 3. (a) Multiyear mean seasonal cycle of observed AERONET AOD $550 \mathrm{~nm}$ at long-term sites in northern Africa and the Middle East. The number of years of data used for each month is shown at the top of the plot area, and the total range of years of observations used is listed under each site name. Whiskers are \pm 1 standard deviation across daily means within a given month. (b) Multiyear mean seasonal cycle of observed AERONET AOD $550 \mathrm{~nm}$ at long-term sites in western and southern Africa. The number of years of data used for each month is shown at the top of the plot area, and the total range of years of observations used is listed under each site name. Whiskers are \pm 1 standard deviation across daily means within a given month.

not possible. Instead, we focus on overall regional patterns, including timing of peaks and minima.

\subsection{Northern Africa and Middle East AERONET AOD and $\alpha_{\text {ext }}$ observations}

The mean AERONET AOD in the northern African and Middle Eastern sites (Table 1, blue in Figs. 1 and 3a) range 0.060.49 and medians range $0.02-0.39$. The maximum multiyear monthly average values range $0.15-0.69$, and minima range 

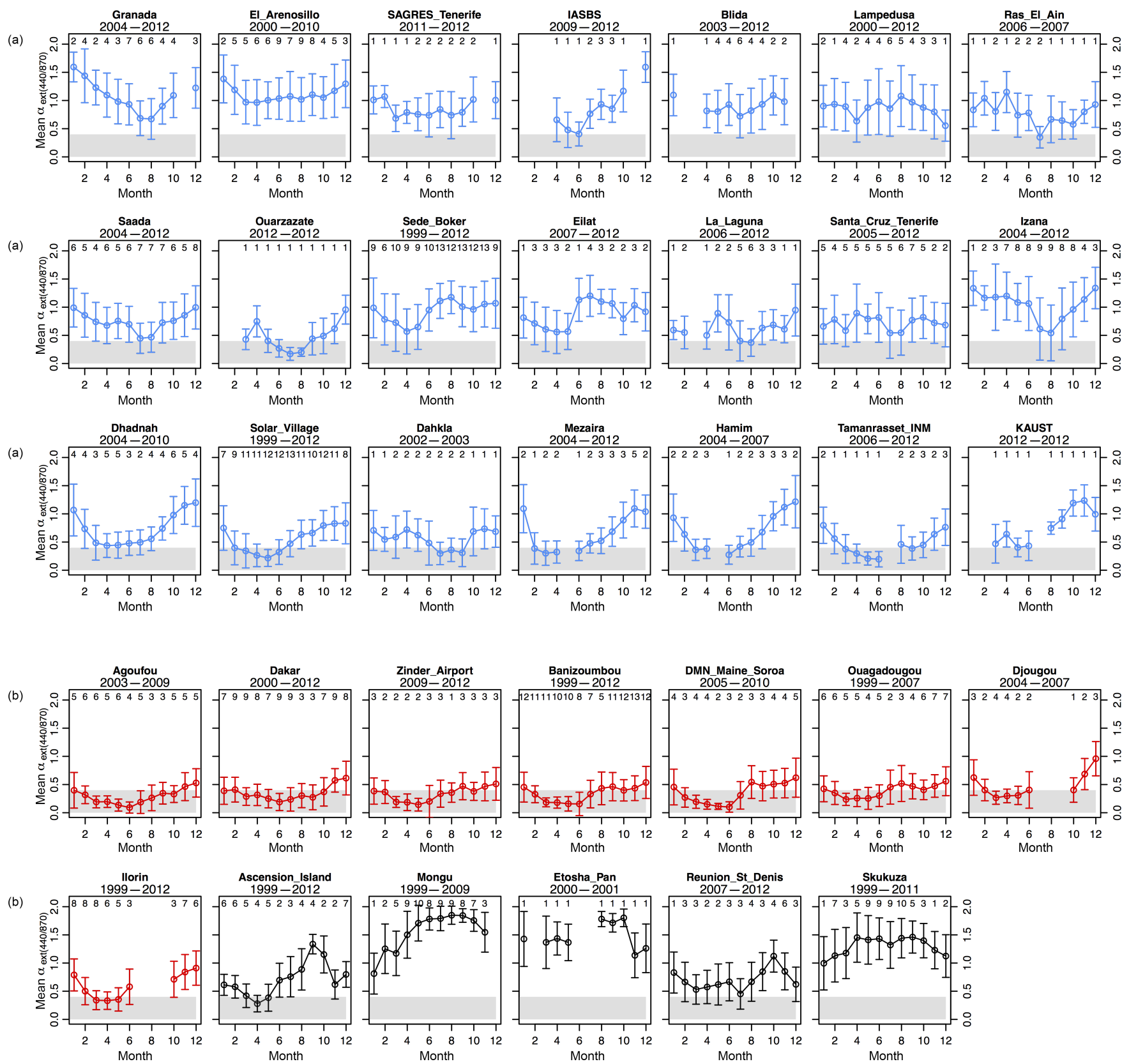

Figure 4. (a) Same as Fig. 3a but for observed $\alpha_{\operatorname{ext}(440 / 870)}$ from AERONET. Gray shaded region represents $\alpha_{\mathrm{ext}(440 / 870)}$ values typical of aerosols dominated by coarse particles (Holben et al., 2001; Ogunjobi et al., 2008). Whiskers are \pm 1 standard deviation across daily means

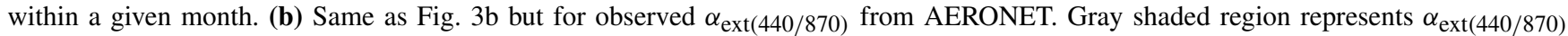
values typical of aerosols dominated by coarse particles (Holben et al., 2001; Ogunjobi et al., 2008). Whiskers are \pm 1 standard deviation across daily means within a given month.

$0.015-0.36$ (Table 2). The average $\alpha_{\text {ext }}$ range $0.49-1.04$ and the medians range $0.41-1.05$. The multiyear monthly average maxima in $\alpha_{\text {ext }}$ range $0.73-1.59$ and minima range $0.17-$ 0.96. The spread of $\alpha_{\text {ext }}$ values suggests a mixture of fine and coarse aerosols at these sites.

The impact of coarse particles on the aerosol loading is observed in this region. Ras El Ain, Ouarzazate, La La- guna, Dahkla, Solar Village, Mezaira, Hamim, and Tamanrasset INM have multiyear monthly average $\alpha_{\text {ext }}$ below the 0.4 "coarse particle" threshold, and all other sites pass this threshold within the standard deviation from the multiyear mean except for El Arenosillo (Fig. 4a). This may be due to the influence of local industrial pollution sources at El Arenosillo (Toledano et al., 2007a, 2009). While low val- 
ues of $\alpha_{\text {ext }}$ could represent other coarse particles besides dust, like sea salt, previous work has indicated sea salt is a minor contributor to aerosols at island sites to the north of Africa, including Izaña (Rodríguez et al., 2011; Putaud et al., 2000; Querol et al., 2009). The correspondence of the seasonality in $\alpha_{\text {ext }}$ and AOD with known dust events suggests mineral dust is the primary contributor to extinction from coarse particles. The maximum AOD occurs across most sites during JuneAugust and coincides with a decrease in $\alpha_{\text {ext }}$. This is later than the AOD peak at the western African sites (Sect. 3.2). This delay and corresponding change in $\alpha_{\text {ext }}$ suggest that transported dust from the Sahara leads to the higher observed AOD. Thus, the seasonal variation in the location of the ITCZ and associated northward shift in dust transport may be responsible for the shift in timing of maximum AOD between the western and northern African sites. AOD at most of the Middle Eastern sites (Eilat, Sede Boker, IASBS, KAUST, and Solar Village) peaks earlier, in March through May, indicative of different seasonality of the local dust sources in the Arabian peninsula (Basart et al., 2009).

The greatest seasonal differences in $\alpha_{\text {ext }}$ occur at Hamim, where in addition to high local dust emissions in spring and summer, regional circulation transports dust from deserts in Iraq and southern Iran during summer and a mixture of fine pollution aerosols from the Persian Gulf throughout the year (Eck et al., 2008; Basart et al., 2009). The Izaña site has a different seasonal pattern in $\alpha_{\text {ext }}$ than its neighboring two sites, La Laguna and Santa Cruz, on the same island. It is, however, the highest elevation site in our study at $2391 \mathrm{~m}$, 1800-2300 m higher than La Laguna and Santa Cruz (see Table 1). Local topography, meteorology, or transport patterns affecting the sinks and sources reaching Izaña may lead to a different aerosol size distribution.

\subsection{Western African AERONET AOD and $\alpha_{\text {ext }}$ observations}

The highest AERONET AOD across all sites is observed in western Africa (denoted in red in Figs. 1 and 3b). The overall mean AOD ranges $0.44-0.67$ and the median values range $0.37-0.56$ (Table 1). AOD peaks at $0.62-1.10$, and minimum AOD ranges 0.26-0.38 (Table 2). The minimum AOD values seen here are similar to the maximum AOD values seen in northern and southern Africa. The western African sites also have low average $\alpha_{\text {ext }}(0.29-0.66)$ and median values $(0.22-0.59)$ (Table 1). The maximum $\alpha_{\text {ext }}$ ranges $0.52-0.96$, and minima range 0.092-0.33 (Table 2). The maximum multiyear monthly average $\alpha_{\text {ext }}$ occurs in December across all western African sites, while the minimum values vary in timing (Table 2).

In general, as AOD increases, $\alpha_{\text {ext }}$ decreases (Figs. $3 b$ and $4 \mathrm{~b}$ ), which would suggest that the variation in the AOD is dominated by the variation in coarse aerosol particles, most likely dust. A similar relationship was found previously for Banizoumbou (Holben et al., 2001; Ogunjobi et al., 2008; Rajot et al., 2008). This relationship is prominent at Agoufou, Banizoumbou, Zinder Airport, Maine Soroa, and Ougadougou. In addition, this relationship is seen in January-June in Djougou, while in October-December the increase in AOD at this site corresponds to an increase in $\alpha_{\text {ext }}$. In Ilorin, which is south of the other sites, the AOD peaks in January-March, while the $\alpha_{\text {ext }}$ is at a minimum value in March-May. Previous work found that minimum values of $\alpha_{\text {ext }}$ are related to dust storms at Ouagadougou, Dakar, and Agoufou and clearly linked to dust at Ilorin and Banizoumbou based on air mass back trajectories and observed seasonality (Ogunjobi et al., 2008). While Dakar is frequently influenced by air transported over the Atlantic Ocean (Ogunjobi et al., 2008), analysis off the coast of Dakar at Cape Verde found the AOD and aerosol mass loading were dominated by desert dust, with sea salt minimally contributing to AOD $(6 \%)$ in part due to its small extinction (Chiapello et al., 1999), which would also imply a minor influence on $\alpha_{\text {ext }}$.

The timing of peak monthly-mean AOD varies between February and March for the Banizoumbou, Ouagadougou, Djougou, and Ilorin sites, and between May and June for the Agoufou, Dakar, Zinder Airport, and DMN Maine Soroa sites, approximately following a south-to-north gradient. The latitudinal movement of dust transport northward from winter (i.e., February-March) to summer (i.e., May-June), thus appears to dictate the seasonal cycle in AOD at these sites, consistent with a previous regional dust model-AERONET comparison at Dakar, Agoufou, and Banizoumbou (Tegen et al., 2013).

Ilorin and Djougou, the most southerly sites in this region, have slightly higher $\alpha_{\text {ext }}$ on average $(0.66 \pm 0.36$ and $0.52 \pm 0.34$, respectively), especially during late fall to early winter (peaking at $\sim 0.9$ in December). This coincides with the sub-Sahelian northern African biomass burning season (December-February) (e.g., Roberts et al., 2009; Giglio et al., 2006). The highest AOD during December-February out of the western African sites is also observed at Ilorin and Djougou (up to a peak of 1.10 in February at Ilorin), which are closer to the primary area of biomass burning during this time (Liousse et al., 2010; Pinker et al., 2010). This suggests that biomass burning aerosols could make up a larger fraction of total AOD at Ilorin and Djougou than elsewhere during this time period, and explains the different relationship in the seasonality of $\alpha_{\text {ext }}$ and AOD at these two sites.

Dakar has the smallest month-to-month variability in AOD, ranging from 0.30 to 0.62. Léon et al. (2009) find that Dakar is subject to transport of both dust and biomass burning aerosols, depending on the season, as well as poorly constrained anthropogenic emissions from the city and other nearby urban centers. This variety of sources, the site's greater distance from dust and biomass burning aerosol sources, and proximity to anthropogenic emissions that have lower seasonal variability may explain its observed seasonal cycle. 


\subsection{Southern African AERONET AOD and $\alpha_{\text {ext }}$ observations}

The average AERONET AOD in the southern African sites ranges $0.064-0.21$ and the medians range $0.06-0.14$, with multiyear monthly maximum AOD peaking at $0.095-0.50$ and minimum AOD ranging 0.046-0.13 (Tables 1 and 2). The region has larger $\alpha_{\text {ext }}$, with averages ranging 0.7-1.6 and medians ranging $0.66-1.75$. The maximum monthly average $\alpha_{\text {ext }}$ ranges $1.12-1.85$ and the minima range $0.28-1.14$. Mongu and Skukuza in southern Africa have the highest observed $\alpha_{\text {ext }}$, indicating little influence from coarse aerosols and confirming the importance of biomass burning as an aerosol source in this region.

Previous studies have shown AOD is highest in this region during the biomass burning season, from AERONET AOD through the year 2007 at Mongu and Skukuza (Queface et al., 2011) and MISR satellite data over South Africa (Tesfaye et al., 2011). Mongu is situated in Zambia in the middle of the biomass burning source region in southern Africa (e.g., Swap et al., 2003; Eck et al., 2003; Edwards et al., 2006; Queface et al., 2011). For southern hemispheric Africa, peak fire activity typically occurs in June through October, with a shift in general toward later months moving from north to south, except in the winter rain areas of southwestern South Africa (Archibald et al., 2010; Giglio et al., 2006).

At Ascension Island, the transport of biomass burning aerosols from southern Africa west over the Atlantic Ocean is observed in the seasonal cycle of $\alpha_{\text {ext }}$ and AOD (Figs. 3b and $4 \mathrm{~b}$ ), as both peak in September, which is the timing of climatological peak AOD and peak biomass burning at Mongu (Giglio et al., 2006). This known transport pathway off the coast of Angola (Garstang et al., 1996) is also seen in the AOD and $\alpha_{\text {ext }}$ observed at Etosha Pan, but peak values occur in October as opposed to September. However, these values at Etosha Pan may not represent a long-term mean seasonal cycle as only 1 year of data was available at this site during the time period of our study.

The AOD at Skukuza also peaks in September, indicating transport of biomass burning aerosols southeast over the site and exiting the continent toward the Indian Ocean, consistent with the so-called "river of smoke" or major export pathway off the coast of southeastern South Africa (e.g., Swap et al., 2003). The eventual transport of biomass burning aerosols from southern Africa over Réunion St. Denis is indicated in the seasonal cycle of $\alpha_{\text {ext }}$ and AOD, which increase toward an October peak.

The continental sites closest to the region of burning have sustained and relatively constant high values of $\alpha_{\text {ext }}$ during April-October (Fig. 4b). This is especially evident at Mongu. The $\alpha_{\text {ext }}$ at all southern African sites declines in austral spring and summer. While these small variations in $\alpha_{\text {ext }}$ alone are not enough to distinguish aerosol size distributions, they are consistent with results from MISR for the central South African region (including Skukuza) that showed an in-
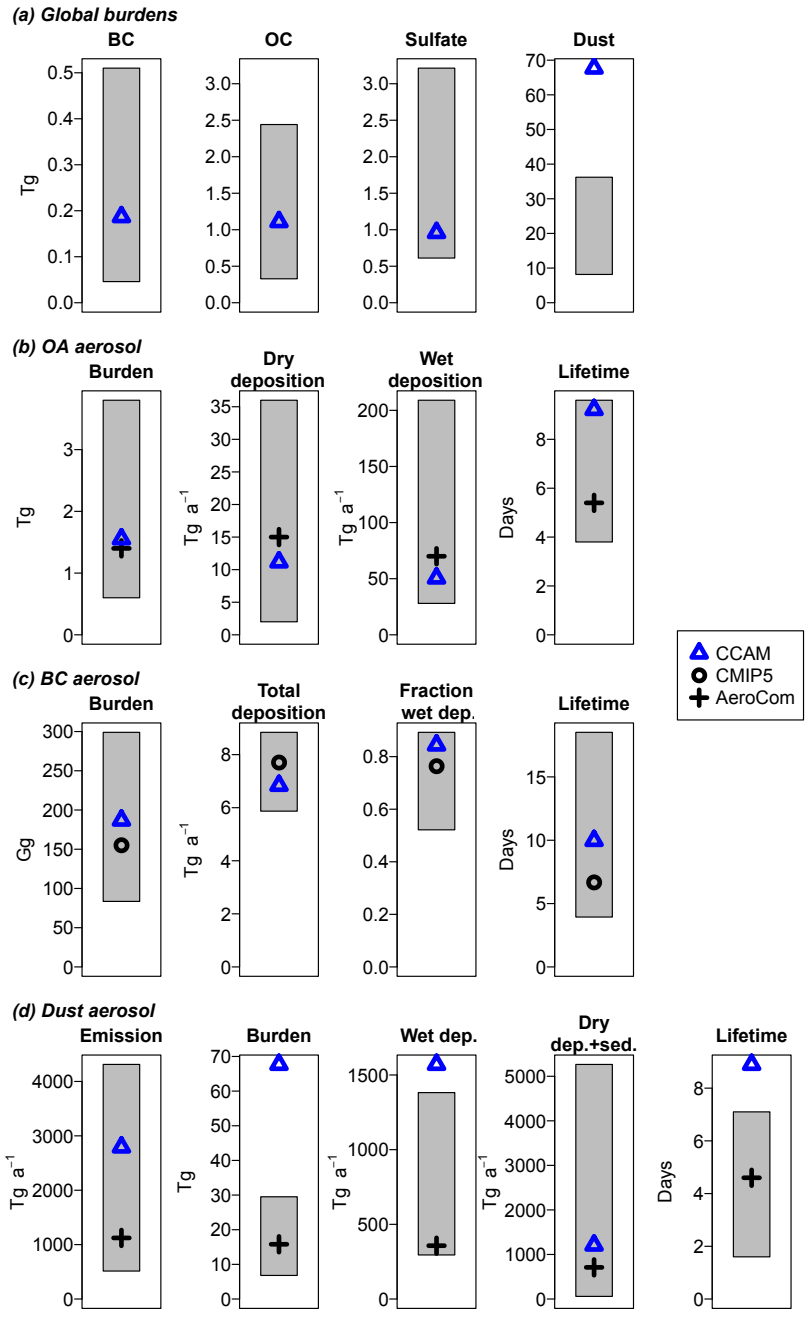

Figure 5. Comparison of present-day model results for CCAM (blue triangles) against ranges from other models (shaded gray area), for (a) global burdens of major aerosol constituents, (b) characteristics of OA aerosol, (c) characteristics of BC aerosol, and (d) characteristic of dust aerosol. Reference model ranges in (a) are from Kinne et al. (2006) with additional models provided from Jathar et al. (2011) for OC, Liu et al. (2005) for sulfate, and Zender et al. (2004) for dust. AeroCom Phase II model ranges and medians (black crosses) in (b) are from Tsigaridis et al. (2014); CCAM modeled OC is converted to OA by multiplying by a factor of 1.4 for a consistent comparison (Tsigaridis et al., 2014). CMIP5 model ranges and medians (black circles) in (c) are from Allen and Landuyt (2014). AeroCom Phase I model ranges and medians (black crosses) in (d) are from Huneeus et al. (2011).

crease in the coarse mode fraction in summer due to dust from the Northern Cape and Namibian desert regions (Tesfaye et al., 2011). 
Table 3. Global and Africa-only annual average burdens, lifetimes, total deposition fluxes, and fraction wet deposition of four prognostic aerosol species in CCAM for the year 2010.

\begin{tabular}{|c|c|c|c|c|c|c|c|c|c|c|}
\hline \multirow[t]{2}{*}{ Species } & \multicolumn{2}{|c|}{$\begin{array}{l}\text { Burden } \\
(\mathrm{Tg})\end{array}$} & \multicolumn{2}{|c|}{$\begin{array}{l}\text { Total deposition } \\
\qquad\left(\mathrm{Tg} \mathrm{a}^{-1}\right)\end{array}$} & \multicolumn{2}{|c|}{$\begin{array}{c}\text { Fraction wet deposition } \\
\text { of total }\end{array}$} & \multicolumn{2}{|c|}{$\begin{array}{l}\text { Lifetime } \\
\text { (days) }\end{array}$} & \multicolumn{2}{|c|}{$\begin{array}{l}\text { Emissions } \\
\left(\mathrm{Tg} \mathrm{yr}^{-1}\right)\end{array}$} \\
\hline & Global & Africa & Global & Africa & Global & Africa & Global & Africa & Global & Africa \\
\hline $\mathrm{BC}$ & 0.187 & 0.0465 & 6.84 & 1.56 & 0.844 & 0.802 & 9.98 & 10.9 & 7.38 & 2.05 \\
\hline $\mathrm{OC}$ & 1.11 & 0.305 & 44.1 & 12.1 & 0.819 & 0.782 & 9.22 & 9.19 & 44.8 & 14.8 \\
\hline Sulfate & 0.961 & 0.161 & 65.1 & 7.18 & 0.865 & 0.833 & 5.39 & 8.16 & 57 & 9.18 \\
\hline Dust & 67.7 & 26.9 & 2780 & 1460 & 0.565 & 0.364 & 8.9 & 6.72 & 2805 & 2320 \\
\hline
\end{tabular}

\section{Model evaluation}

\subsection{Annual model aerosol budgets}

Annual burdens, deposition, wet deposition fraction, lifetime, and emissions for each of the four prognostic aerosol species in 2010 are shown in Table 3 for the globe and the African domain $\left(40^{\circ} \mathrm{S}\right.$ to $40^{\circ} \mathrm{N}, 20^{\circ} \mathrm{W}$ to $\left.60^{\circ} \mathrm{E}\right)$, separately. These values are compared to estimates from other presentday models and the CMIP5 and AeroCom experiments in Fig. 5.

CCAM is within the range of global present-day annual aerosol burden estimates from models in the CMIP5 and AeroCom experiments for $\mathrm{BC}, \mathrm{OC}$, and sulfate. In addition, in Fig. 5b-c, CCAM is within the range of estimates for total deposition, wet deposition fraction, burden, and lifetime of organic aerosols (OAs) and BC (Tsigaridis et al., 2014; Allen and Landuyt, 2014). CCAM modeled OC emissions and burden is converted to OA by multiplying by a factor of 1.4 for a consistent comparison (Tsigaridis et al., 2014). In general the CCAM values for $\mathrm{BC}$ burden and lifetime are higher than the CMIP5 median values, but are well within the range of models. For OA, CCAM is close to median estimates from the AeroCom Phase II models with the exception of OA lifetimes, which is at the high end of all models.

While CCAM performs well compared to other models for $\mathrm{BC}, \mathrm{OC}$, and sulfate, CCAM has a dust burden $(68 \mathrm{Tg}) \sim 2-7$ times higher than AeroCom Phase I models (Huneeus et al., 2011) and all available dust modeling results summarized in a recent review (Kinne et al., 2006; Zender et al., 2004) (see Fig. 5a, d). In the CCAM model, annual dust emissions over the African region alone $\left(40^{\circ} \mathrm{S}\right.$ to $40^{\circ} \mathrm{N}, 20^{\circ} \mathrm{E}$ to $\left.60^{\circ} \mathrm{W}\right)$ in 2010 are $2320 \mathrm{Tg} \mathrm{yr}^{-1}$, contributing $83 \%$ of global total modeled dust emissions. The range from AeroCom models is 35-77.9\% of global dust emissions (Huneeus et al., 2011). Global dust emissions (Fig. 5) are above the mean, but within the range of AeroCom models. This together with an overestimation of dust in Africa would lead to a large percentage contribution of global dust emissions from Africa.

The global dust emissions, burden, wet deposition, dry deposition and sedimentation, and lifetime are compared to AeroCom experiments in Fig. 5d (Huneeus et al., 2011).
The modeled dust lifetime ( 8.9 days) is longer than models examined in Zender et al. (2004) that range from 2.8 to 7.1 days, and in AeroCom Phase I that range from 1.6 to 7.1 days (Huneeus et al., 2011), indicating the sinks of dust in the model may be too low, contributing to a high global dust burden. The wet deposition $\left(1571 \mathrm{Tga}^{-1}\right)$ is higher than AeroCom results (range of 295 to $1382 \mathrm{Tg} \mathrm{a}^{-1}$, median $\left.357 \mathrm{Tg} \mathrm{a}^{-1}\right)$; however, the dry deposition and sedimentation $\left(1209 \mathrm{Tg} \mathrm{a}^{-1}\right)$ are similar to the AeroCom median $\left(753 \mathrm{Tg} \mathrm{a}^{-1}\right)$ in spite of the much higher dust burden. This overestimation of dust is discussed more in Sect. 4.2.2 and 4.2.3 below.

\subsection{Evaluation of model against AERONET AOD observations: multiyear mean seasonal cycle comparison}

Figure 6 shows the same multiyear mean seasonal cycle for observed AERONET AOD as in Fig. 3 (here in red triangles), overlaid with CCAM results for all model years (dark blue) and only those months with corresponding AERONET data that met the $70 \%$ completeness cutoff (yellow). The shaded red areas are within \pm 1 standard deviation from the observed values, and the shaded blue areas are within \pm 1 standard deviation from the CCAM output for all model years. In this comparison, only AERONET sites with multiple years of complete data for most of the annual cycle are included in order to compare multiyear monthly cycles from observations and the model.

The monthly cycle from CCAM considering the full model period (dark blue line) and only those years with observational data (yellow line) are similar across all sites, with only minor differences that are within \pm 1 standard deviation of the full model period. Thus, the full model time period (1999-2012) can be used to evaluate modeled spatial patterns against all available AERONET sites, even though the observations at different sites are from disparate time periods. All following analyses are presented using the full model time period.

For most sites, the monthly cycle (i.e., timing of peak and minimum AOD) is well captured by CCAM, indicating that the seasonality in CMIP5 emissions and the model parame- 
(a)
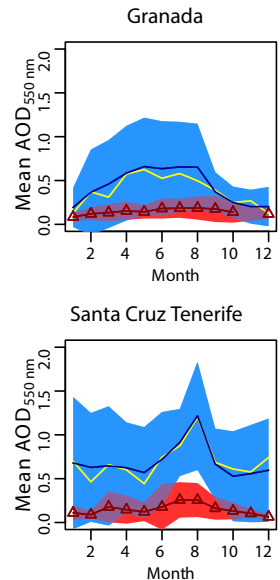

ife
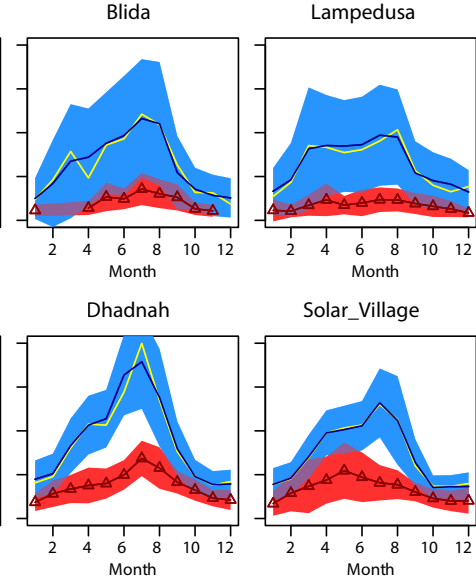

Solar_Village
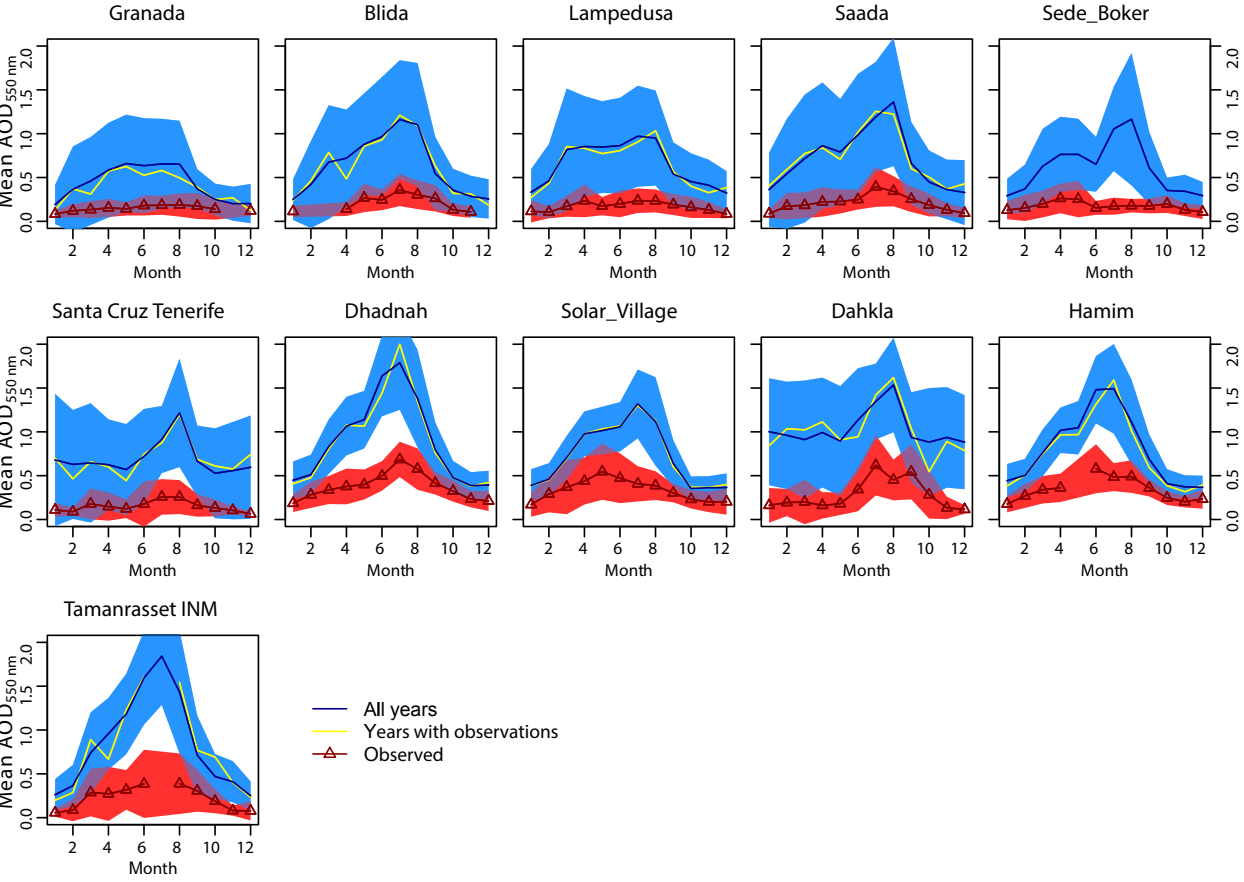

— All years

Years with observation

$\triangle$ Observed

(b)
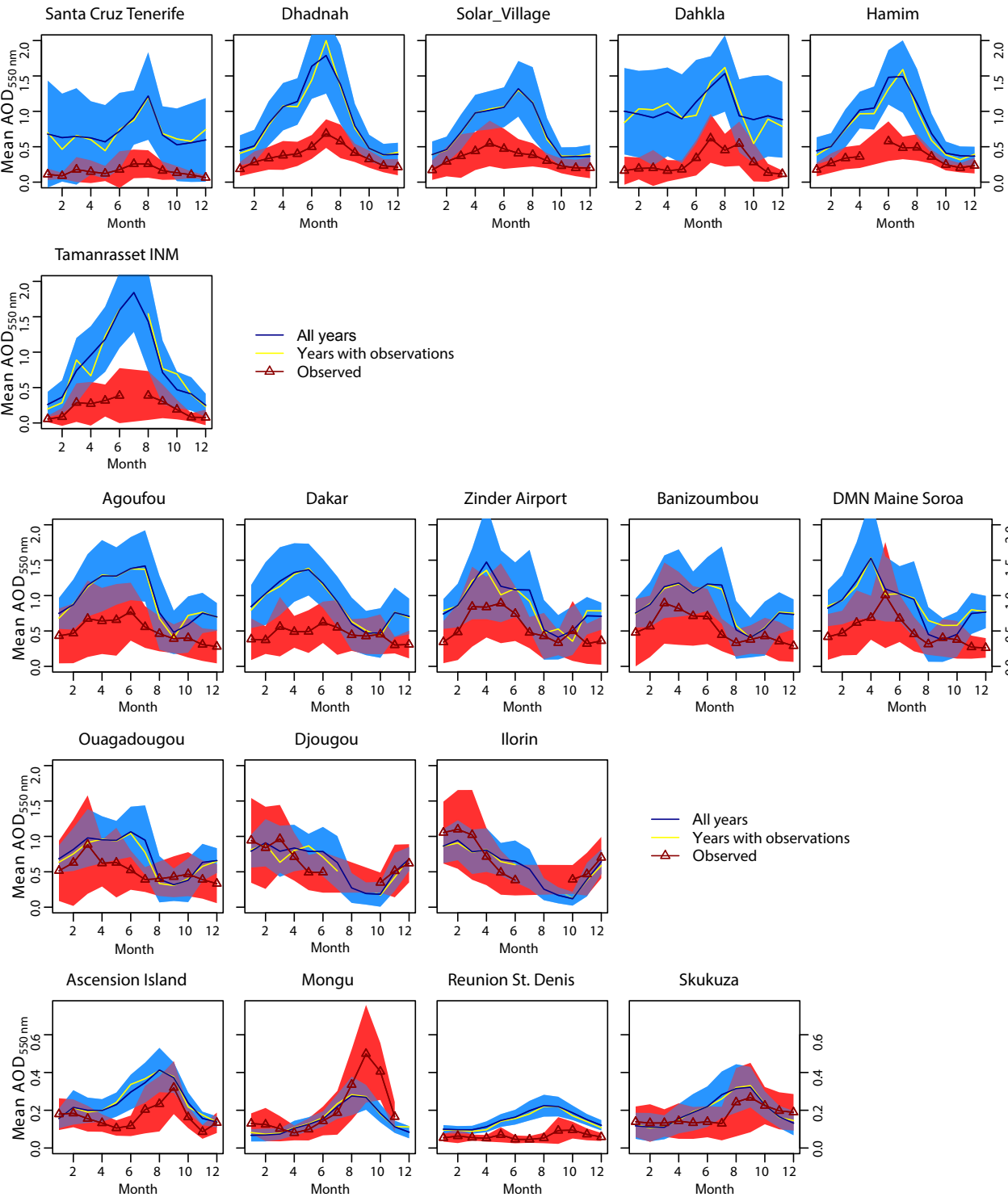

Figure 6. Multiyear mean seasonal cycle of AOD $_{550 \mathrm{~nm}}$ for observed (red) and modeled with all CCAM outputs, 1999-2012 (blue), and only those months with AERONET data meeting the $70 \%$ completeness cutoff (yellow). The \pm 1 standard deviation for the observations and CCAM 1999-2012 output across daily means within a given month is shaded. 
terization of dust emissions are adequate. A few notable exceptions (e.g., timing of maxima at Mongu and Ascension Island, missing winter minima in western African sites, and missing summertime peaks after observed springtime maxima at Sede Boker and Solar Village) will be investigated in Sect. 4.2.1-4.2.3 below. The magnitude of modeled and observed multiyear monthly average AOD overlap within \pm 1 standard deviation of each other for at least 7 months at all sites except Réunion St. Denis, and for all observed months at 8 sites that span all three regions (Granada, Blida, Zinder Airport, Banizoumbou, Ouagadougou, Djougou, Ilorin, and Skukuza). The differences in magnitude per region will also be detailed in Sect. 4.2.1-4.2.3 below.

Figure 7 highlights two representative sites each from the northern, western, and southern regions with the most observational data available in greater detail, comparing multiyear monthly mean observed and modeled AOD, with the modeled contribution of each aerosol type (sea salt, large size bin dust (radius $\geq 1 \mu \mathrm{m}$ ), small size bin dust (radius $<1 \mu \mathrm{m}$ ), BC, OC, sulfate) to total AOD shown. Further investigation of model performance, by region, follows.

\subsubsection{Southern Africa}

In comparison to the other regions, the model better represents the magnitude of AOD at the southern African sites (except for Réunion St. Denis), with a smaller normalized mean bias and mean absolute error (see Fig. 6 and Table 4). However, the timing of the modeled peak AOD at two of the sites where maximum AOD is dominated by biomass burning (Ascension Island and Mongu) occurs 1 month too early (in August, instead of September as highlighted in Table 2). Modeled AOD at both Mongu and Skukuza remain relatively constant between August and September (Fig. 7). This is consistent with the observations at Skukuza, likely due to the greater influence of anthropogenic aerosol sources at this site. Figure 7 shows the modeled sulfate contribution (emitted from both anthropogenic and biomass burning) to total AOD is higher and that of OC (primarily emitted from biomass burning) is lower at Skukuza relative to Mongu, indicating that the breakdown of model emissions sources is consistent with this explanation. There is a larger observed increase in AOD between August and September at the biomass burning source region (Mongu) and the more remote Ascension Island, whose seasonality is impacted by transported biomass burning aerosol as seen in the $\alpha_{\text {ext }}$ (Fig. 4a and $b$ ).

This mismatch in timing of the peaks is a long-standing issue in understanding southern African biomass burning, first noted during the SAFARI-2000 measurement campaign (Swap et al., 2003). In a study of southern hemispheric biomass burning observed by satellite, Edwards et al. (2006) found that in southern Africa alone, peak $\mathrm{CO}$ and AOD lagged peak fire counts by $\sim 1$ month (late September to October vs. late August, respectively). Using a chemical trans- port model, they found that the residence time of $\mathrm{CO}$ over the region was much too short for transport patterns to explain the 1-month time lag (Edwards et al., 2006). Two recent modeling studies also found that peak AOD over southern hemispheric Africa lagged peak fire counts and estimates of peak biomass burning emissions using either the GFEDv2 or AMMA inventories by 1-2 months (Magi et al., 2009; Tummon et al., 2010). The CMIP5 emissions used in our CCAM model study are from GFEDv2 for the year 2000 onward (van der Werf et al., 2006; Lamarque et al., 2010) and peak in August at the source region of Mongu, leading to the maximum modeled AOD. The GFED inventory is based on estimates of burned area from burn scars and thermal signatures of active fires viewed by the MODIS satellite, combined with land cover data and meteorological parameters to estimate emissions for different vegetation types (van der Werf et al., 2006, 2010). This type of method would only capture large fires that produce satellite-detectable burn scars. A recent study updated the GFED inventory to include a parameterization of fire counts, burned area, and emissions from previously missing small fires, but this did not change the seasonality in biomass burning emissions over southern hemispheric Africa (Randerson et al., 2012). Burned area still peaked in August, as it increased more early in the biomass burning season than late in the season when small fires were included, and higher fuel load burns (e.g., from dense, wooded vegetation) late in the season did not lead to a compensating change in emissions (Randerson et al., 2012). The small fires parameterization still relies on detection of thermal anomalies (Randerson et al., 2012).

The observed AOD peak in September aligns with the peak in fire intensity found in the generalized fire regime of savanna-woodland in Archibald et al. (2010). The peak in fire intensity in southern Africa as well as fire size occurs later in the season than the peak in fire number, though the increase in these is not large over the season (Archibald et al., 2010). However, this does suggest that fire intensity may be an important factor to consider in modeling emissions from biomass burning in southern Africa, e.g., through the new initiative FireMIP (Hantson et al., 2016).

Table 4 displays a summary of model-observation comparison by site. The normalized mean bias of the model is negative at Mongu $(-21.2 \%)$ and positive at the three other southern African sites, showing that overall AOD is underestimated at the biomass burning source and overestimated at receptor regions (Table 4). Figure 6 suggests the model overestimates transport of biomass burning emissions to receptor sites in particular for the months of June through August. Because the AOD in both the model and observations are smaller here than in other regions, the mean absolute error is very low (0.07-0.09) and is the lowest of all sites in this model comparison. At all sites except Réunion St. Denis, the model captures some of the temporal variability, with highly statistically significant correlation coefficients ranging from 0.48 to 0.67 . Relative to other regions, the model performs 

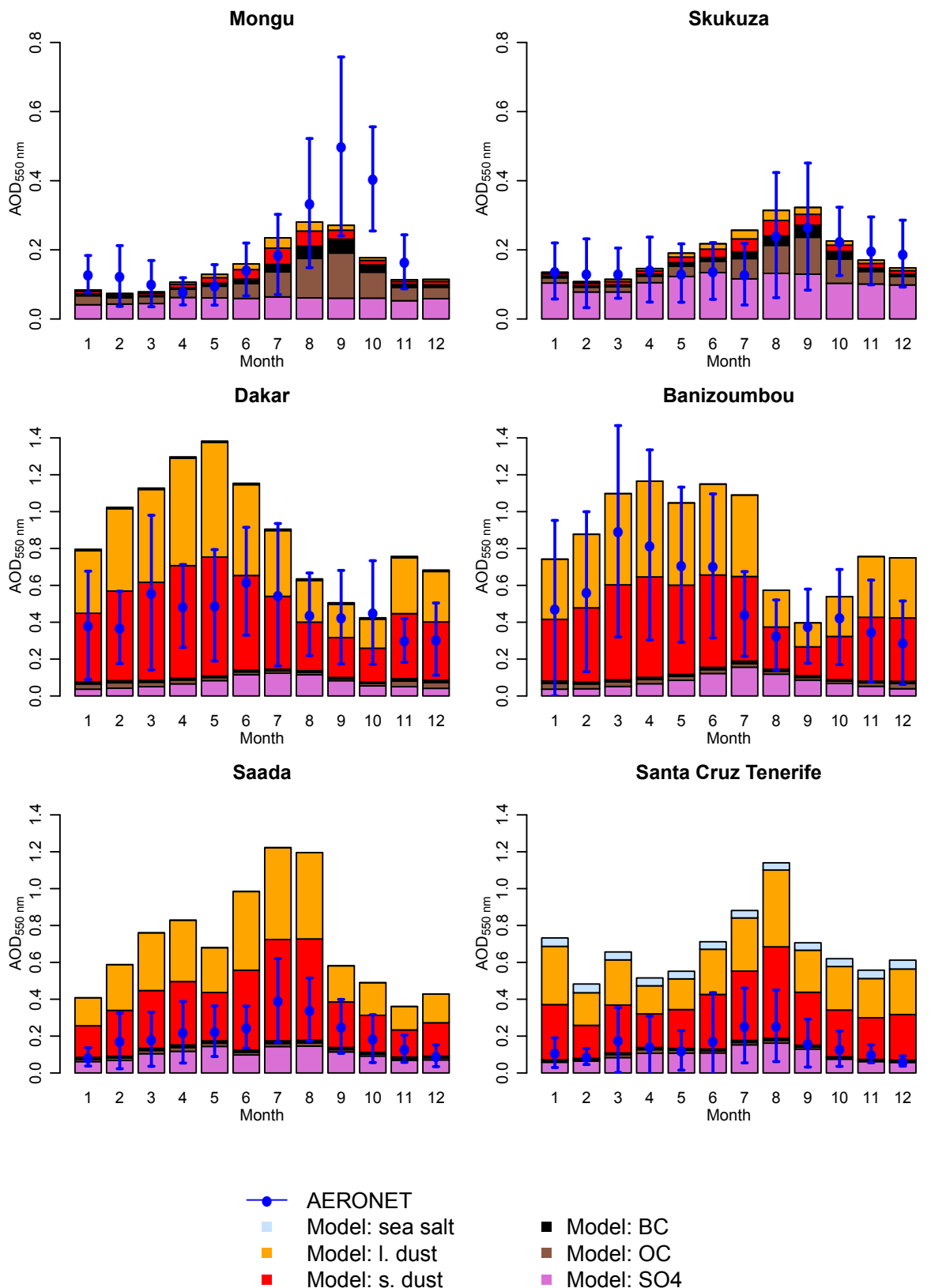

- Model: BC

- Model: OC

- Model: SO4

Figure 7. Multiyear mean observed vs. modeled seasonal cycle of $\mathrm{AOD}_{550 \mathrm{~nm}}$ at six AERONET sites. Modeled $\mathrm{AOD}_{550 \mathrm{~nm}}$ is broken down into the contribution from each aerosol species (sea salt, large size bin dust (radius $\geq 1 \mu \mathrm{m}$ ), small size bin dust (radius $<1 \mu \mathrm{m}$ ), $\mathrm{BC}$, OC, sulfate $\left.\left(\mathrm{SO}_{4}\right)\right)$.

best over southern Africa in terms of mean AOD magnitude, but overestimates the transport of biomass burning aerosols to Réunion St. Denis in June through September.

\subsubsection{Western Africa}

At the western African sites, which in the observations are dominated by dust (Fig. 4b), the model captures the overall seasonal cycle in AOD except between September and December, where the observations show a decrease at all sites except the two southernmost (Djougou and Ilorin) while the model increases (see Fig. 6). As a result, the modeled minimum AOD occurs between August and October, instead of in November-December as in the observations at Agoufou, Dakar, Zinder Airport, Banizoumbou, DMN Maine Soroa, and Ouagadougou.

Figure 7 shows in a case study for two sites, Dakar and Banizoumbou, the strong influence of dust on these sites. The increase in modeled AOD from September through Decem- 
Table 4. Summary of model-observation comparison of monthly-average AOD $_{550 \mathrm{~nm}}$. The significance of the Pearson's correlation is indicated by “*” for $p<0.05$, “**” for $p<0.01$, and “***” for $p<0.001$; NS is not significant at 0.05 level.

\begin{tabular}{|c|c|c|c|c|c|c|c|}
\hline & & Site & $\begin{array}{r}\text { Correlation } \\
\text { coefficient }(r)\end{array}$ & & $\begin{array}{l}\text { Normalized mean } \\
\text { bias }^{\text {a }}\end{array}$ & $\begin{array}{r}\text { Mean absolute } \\
\text { error }^{\mathrm{a}}\end{array}$ & $\begin{array}{r}\text { Number of } \\
\text { months }\end{array}$ \\
\hline \multirow{11}{*}{ 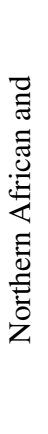 } & \multirow{11}{*}{ 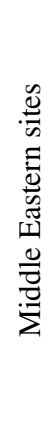 } & Granada & 0.47 & $* * *$ & $176.6 \%$ & 0.27 & 50 \\
\hline & & Blida & 0.70 & $* * *$ & $220.0 \%$ & 0.54 & 33 \\
\hline & & Lampedusa & 0.58 & $* * *$ & $278.2 \%$ & 0.51 & 46 \\
\hline & & Saada & 0.60 & $* *$ & $231.7 \%$ & 0.50 & 74 \\
\hline & & Sede Boker & 0.23 & $*$ & $245.5 \%$ & 0.43 & 129 \\
\hline & & Santa Cruz Tenerife & 0.44 & $* * *$ & $339.1 \%$ & 0.54 & 60 \\
\hline & & Dhadnah & 0.81 & $* * *$ & $125.1 \%$ & 0.45 & 50 \\
\hline & & Solar Village & 0.51 & $* * *$ & $121.1 \%$ & 0.42 & 128 \\
\hline & & Dahkla & 0.49 & $*$ & $242.2 \%$ & 0.75 & 19 \\
\hline & & Hamim & 0.82 & $* * *$ & $115.2 \%$ & 0.37 & 28 \\
\hline & & Tamanrasset INM & 0.89 & $* *$ & $253.6 \%$ & 0.51 & 19 \\
\hline \multirow{8}{*}{ 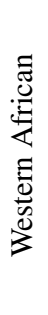 } & \multirow{8}{*}{$\stackrel{\infty}{\omega}$} & Agoufou & 0.51 & $* *$ & $89.7 \%$ & 0.47 & 58 \\
\hline & & Dakar & 0.33 & $* *$ & $103.2 \%$ & 0.48 & 95 \\
\hline & & Zinder Airport & 0.61 & $* *$ & $59.3 \%$ & 0.35 & 30 \\
\hline & & Banizoumbou & 0.50 & $* *$ & $58.6 \%$ & 0.34 & 126 \\
\hline & & DMN Maine Soroa & 0.52 & $* *$ & $94.5 \%$ & 0.46 & 41 \\
\hline & & Ouagadougou & 0.27 & $*$ & $29.3 \%$ & 0.28 & 61 \\
\hline & & Djougou & 0.29 & NS & $-1.3 \%$ & 0.20 & 24 \\
\hline & & Ilorin & 0.59 & $* *$ & $-12.6 \%$ & 0.22 & 61 \\
\hline \multirow{4}{*}{ 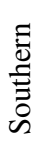 } & \multirow{4}{*}{ 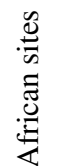 } & Ascension Island & 0.51 & $* *$ & $41.8 \%$ & 0.09 & 53 \\
\hline & & Mongu & 0.67 & $* *$ & $-21.2 \%$ & 0.09 & 77 \\
\hline & & Réunion St. Denis & 0.21 & NS & $135.0 \%$ & 0.09 & 84 \\
\hline & & Skukuza & 0.48 & $* *$ & $24.6 \%$ & 0.07 & 72 \\
\hline
\end{tabular}

ber, which is not seen in the observations, is due to increases in the large dust (orange bars) and small dust (red bars) contribution. This could be due to the systematic overestimation of $10 \mathrm{~m}$ wind speed during the dry season in the ERA-Interim reanalysis, a problem common to several meteorological reanalyses in the Sahelian region (Largeron et al., 2015). Although the ERA-Interim reanalysis used in this study was found to perform best overall against wind speed observations, it also exhibited a strong positive bias during northern hemispheric winter (Largeron et al., 2015). Given that the CCAM simulations are nudged within the ERA reanalysis data, this may contribute to an overestimation of wind-driven dust emissions into the CCAM atmosphere during this season (September-December).

The remainder of the shape of the seasonal cycle is captured relatively well at western African sites, with the peaks in AOD in CCAM occurring within 1 month of the peak in AERONET AOD. Only at Ilorin is the timing of the peak the same in the model and the observations. Correlation coefficients between the modeled and observation AOD are statistically significant ( $r$ ranges $0.27-0.61$ ) at all sites except Djougou (Table 4). The lack of statistically significant correlation at Djougou may in part be due to a lack of data with only 24 individual months. In most of the western African sites, the model has an overall positive normalized mean bias (ranging from 29 to $103 \%$ ). The exceptions are Djougou and Ilorin, which are the two southernmost sites. Djougou and Ilorin are slightly farther away from major dust sources originating in topographic depressions (Evan et al., 2015), which are represented in the CCAM dust emissions scheme (Rotstayn et al., 2011), and have relatively small, but negative normalized mean biases $(-1.3,-12.6 \%$, respectively). The mean absolute error for all sites ranges $0.20-0.48$, which are higher than southern Africa, but lower than northern Africa, which has lower AOD on average compared to the western African sites.

The model overestimations in AOD at western African sites closer to the dust source regions may be due to an overestimation of wind speeds. Largeron et al. (2015) found that on an annual mean scale, ERA-Interim overestimates observed $10 \mathrm{~m}$ wind speeds by $0.27 \mathrm{~m} \mathrm{~s}^{-1}$ in the Sahel, but this was largely a result of the wintertime overestimate mentioned previously. In fact, wind speeds during springtime and the monsoon season were underestimated in the ERA-Interim because the reanalysis did not represent large increases in wind speed from boundary layer free convection and deep 
convection (Largeron et al., 2015). Previously, the CSIRO Mk3 coupled global climate model (GCM) accounted for this by estimating subgrid gustiness from both the boundary layer and deep convection to increase the effective $10 \mathrm{~m}$ wind speed used in the model dust emission parameterization (Ginoux et al., 2004). In the case of CCAM, it was found that the effective subgrid-scale winds were too high (compared to the CSIRO Mk3 simulations), possibly due to differences in vertical and horizontal resolution, as well as changes in the model physical parameterizations. This led to an overestimation of global total dust emissions that were far outside the range suggested by observations (Rotstayn et al., 2011, 2012). Therefore, these subgrid gustiness terms have been removed from the model version presented here. In spite of this, it is still possible that $10 \mathrm{~m}$ winds in the model may be too high. Part of the determination of surface wind speeds in CCAM relies on the Community Atmosphere-Biosphere Land Exchange (CABLE) model estimate of surface roughness. Dust emissions additionally depend on local soil moisture and soil texture from the CABLE land surface model. Issues with modeled precipitation and wet deposition, the response of soil moisture to precipitation, and how recent changes to soil texture implemented in CABLE from the Harmonized World Soil Database affect the atmospheric simulation could all contribute to an overestimate in dust emissions and atmospheric dust concentrations.

\subsubsection{Northern Africa and Middle East}

Potential issues with dust emissions and transport in CCAM become more apparent when comparing to northern African AOD observations. There are substantial overestimates of the multiyear monthly mean AOD in northern Africa (see Fig. 6) of up to a factor of 8 to 42 for individual months at each site. This region has the highest normalized mean biases, with NMB over $200 \%$ at 6 of the 11 sites (see Table 4). As shown in Fig. 7 for two of the northern sites, Saada and Santa Cruz Tenerife, almost all modeled AOD in this region comes from dust. However, the observational data indicate that Saada and Santa Cruz Tenerife rarely experience low values of $\alpha_{\text {ext }}$ reaching the threshold representative of coarse dust (Fig. 4a). Thus, CCAM overestimates the contribution of dust to AOD over Saada and Santa Cruz Tenerife. The global dust burden in CCAM $(67 \mathrm{Tg})$ is more than twice that of the high end of values in a recent review of global dust models as well as AeroCom and CMIP5 models (Zender et al., 2004). Global dust emissions are higher than the median but are well within the range of estimates from Zender et al. (2004) and AeroCom models (Huneeus et al., 2011) (see Fig. 5). It is possible that an overestimate of dust lifetime combined with an overestimate of dust emissions plays a major role in this issue (see Sect. 4.1). At the same time, over the Arabian Peninsula (Dhadnah, Solar Village, Hamim) the model performs better with the lowest mean biases across sites in northern Africa and the Middle East (Table 4), sug- gesting dust emissions and transport may be better characterized in this region.

However, the model does capture the monthly trends in observed AOD, with a strong peak in boreal summer and relatively lower values through rest of the year. At Saada, Santa Cruz Tenerife, and Dahkla, CCAM AOD peaks in August, while the observations peak in July. Modeled and observed AOD peaks in June at Hamim and July at Blida and Dhadnah. At Tamanrasset INM, CCAM AOD also peaks in July; however, there are no data for July at that site. The model output shows a higher proportion of dust AOD relative to total AOD in the summer months, especially July and August (Fig. 7), which is consistent with the observed decrease in $\alpha_{\text {ext }}$ and known northward movement of Saharan dust transport in summer from the shifting ITCZ (Jankowiak and Tanre, 1992; Moulin et al., 1997; Léon et al., 2009; Schepanski et al., 2009). The model also reproduces the increase in fine aerosol (e.g., $\mathrm{BC}$ and $\mathrm{SO}_{4}$ ) relative to coarse dust in winter months at the two sites (Fig. 7) as implied by the increasing observed $\alpha_{\text {ext }}$ (Fig. 4a). A small impact of simulated sea salt can be seen at the Santa Cruz Tenerife site (Fig. 7) (mean AOD of 0.04). The sea salt contribution to simulated monthly AOD at $550 \mathrm{~nm}$ from AeroCom Phase IIICTRL2015 (AeroCom Phase II Interface, 2017) ranges from negligible to greater than 0.1 at Santa Cruz Tenerife.

In spite of the high model bias, all sites in northern Africa and the Middle East have statistically significant correlations, including some of the highest correlation coefficient values (ranging from 0.23 to 0.89). At Sede Boker, which has the lowest correlation coefficient in this region, the model predicts an increase in AOD from June to August, similar to other northern African sites, which is not observed. This discrepancy may be caused by an overestimate of Saharan dust transported to the site during summer.

\subsubsection{Daily variability in modeled and AERONET AOD}

Figure 8 shows probability densities for daily average AOD at each of the 23 evaluation sites, with that observed by AERONET in black and modeled in red. In general, the model at most sites has a wider and smoother distribution of AOD than that observed. This is consistent with modeling limitations from the spatial resolution, 6-hourly time resolution of nudging to reanalysis meteorological data, low time resolution of anthropogenic and biomass burning emissions, and highly parameterized dust emissions (see Sect. 2.1). The modeled daily AOD distribution is particularly more broad and smooth than that observed for sites in northern Africa and the Middle East, where CCAM had the largest positive model biases against observed monthly mean AOD (see Sect. 4.2.3; Table 4). Very low AERONET AOD is frequently observed, and high AOD events associated with dust are sporadic. Modeled dust events appear to be too frequent in this region. In addition, the model is unable to capture the very 

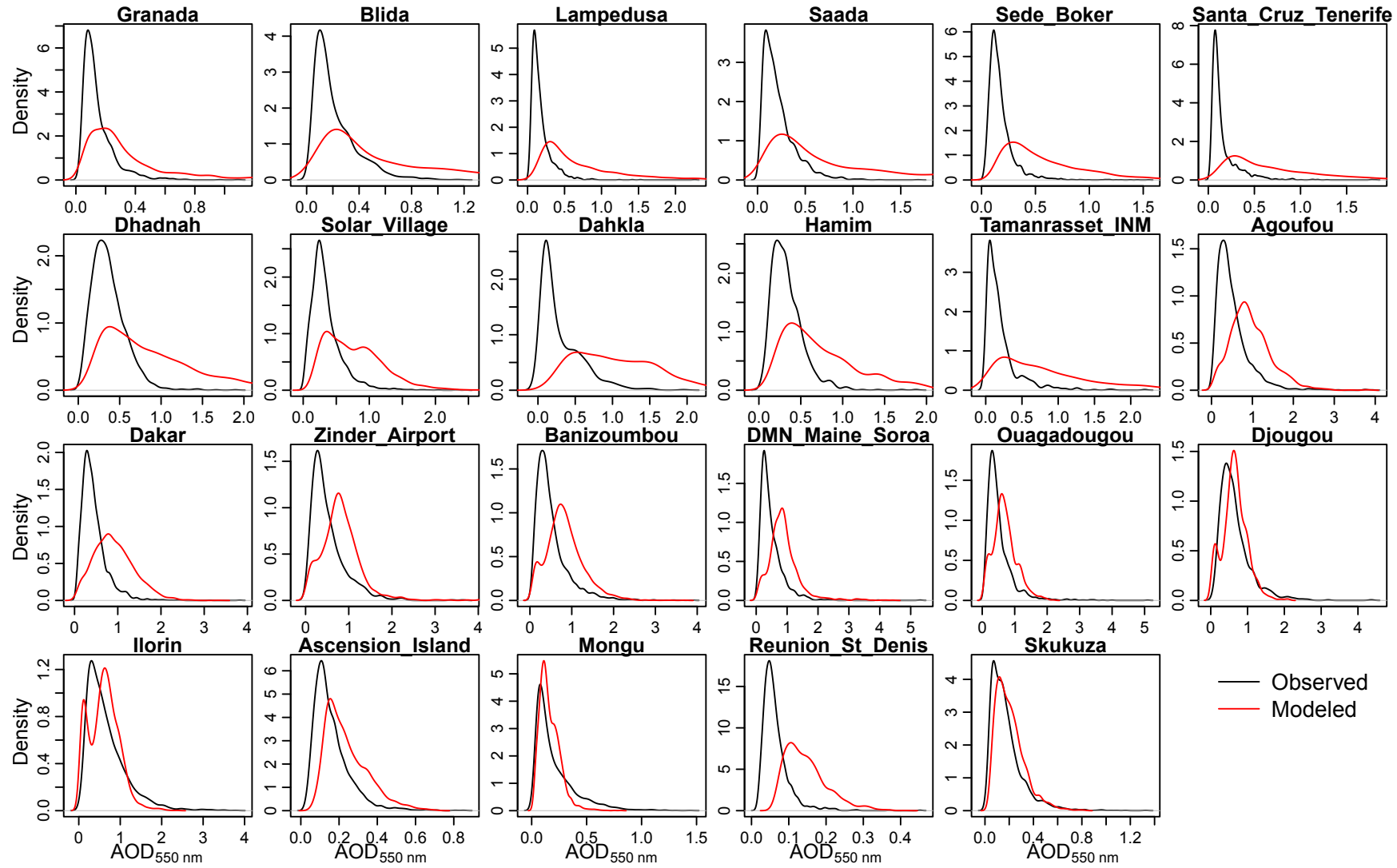

Figure 8. Comparison of the probability densities of modeled (red) and observed (black) daily average $\mathrm{AOD}_{550 \mathrm{~nm}}$ at each site.

low AOD days at Lampedusa, Sede Boker, Santa Cruz Tenerife, and Dahkla. These sites had the largest modeled NMB against monthly mean observed AOD after Tamanrasset INM (Table 4). The modeled monthly mean AOD performs relatively well against AERONET observations at Hamim and Dhadnah relative to other sites in northern Africa and the Middle East, with high correlation coefficients and low NMB (Table 4). These two sites have the highest median observed daily AERONET AOD after Tamanrasset INM in this region (Table 1) and in Fig. 8 have a broader peak at higher AOD that the model is better able to represent. At most sites in western Africa, modeled AOD has a bimodal distribution that is not present in the observations. The secondary peak at low values of AOD suggests the model may be able to simulate aerosol removal processes and/or the absence of dust events, but this does not occur with enough frequency. The model represents the observed daily AOD distribution well at Mongu and Skukuza, near biomass burning sources, in spite of modeled emissions varying only on a monthly timescale. This is similar to previous work which suggested daily variability in observed and modeled AOD in this region was impacted mostly by meteorology (Myhre et al., 3003). However, the AERONET observations show occasional high ( $>1$ ) AOD events that the model cannot represent, likely due to the time averaging of emissions.

\subsubsection{Spatial patterns}

Figure 9 shows the multiyear monthly mean climatology of modeled (background) and observed (filled circles) AOD for March (Fig. 9a), representing high AOD at many western African sites, and September (Fig. 9b), the peak observed AOD at many southern African sites impacted by biomass burning (note the different scales for the two months). Panels showing the 5th and 95th percentiles of 6-hourly CCAM AOD highlight the modeled variability and additional spatial features. The scales are consistent across the maps within each month to aid in comparison and as such some high AOD values are saturated in the color scale (see legend in Fig. 9).

We take advantage of the high temporal and spatial resolution of the model to show how significantly an individual 6-hourly output, in this example within the months of March and September (Fig. 9), can depart from the multiyear monthly mean AOD. Given that the emissions of all aerosol species and their precursors (with the exception of dust) vary only on a monthly to multiannual timescale in CMIP5 emissions (see Sect. 2.1), the variability at the 6hourly timescale must be a result of transport and aerosol sinks in the model (and dust emissions for western and northern Africa). This confirms the importance of model processes driven by meteorology to modeled AOD. In southern hemi- 
(a) March

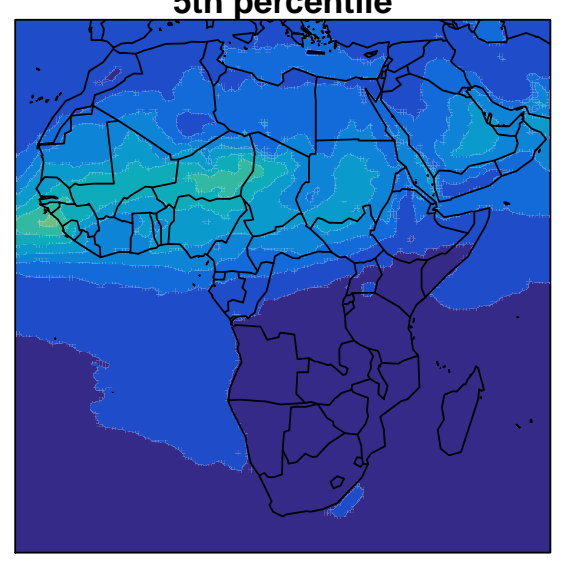

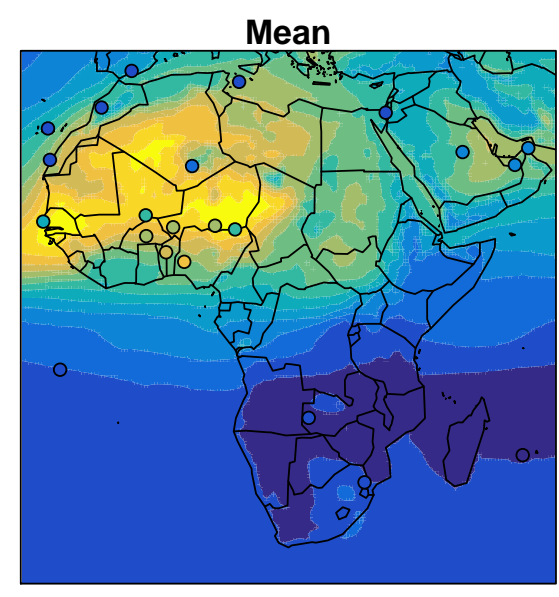

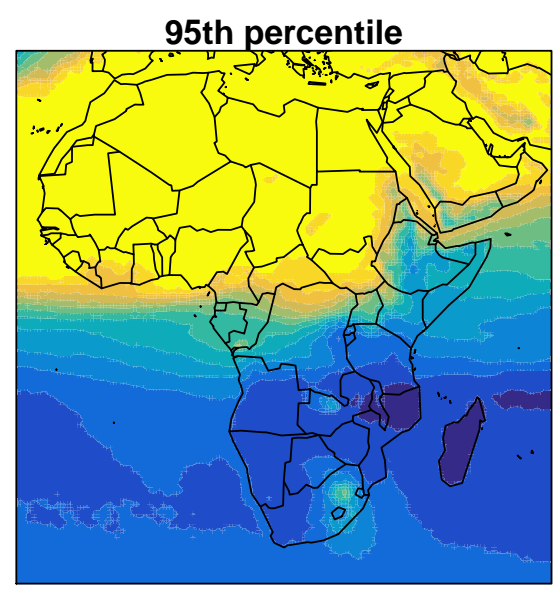

(b) September

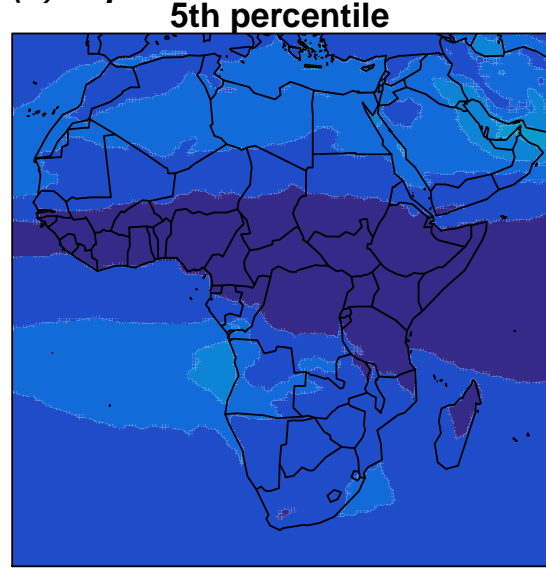

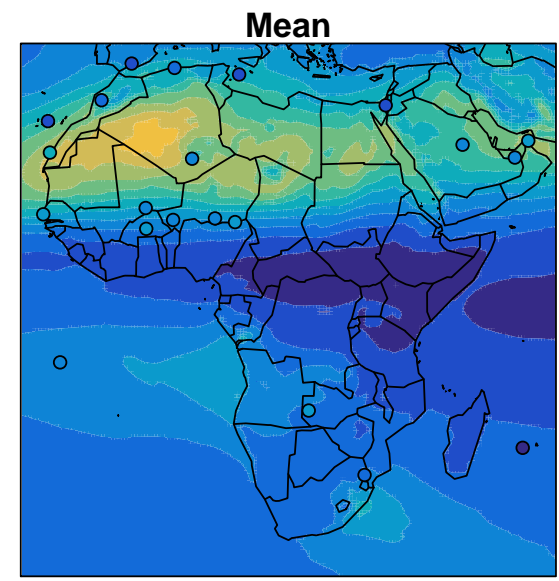

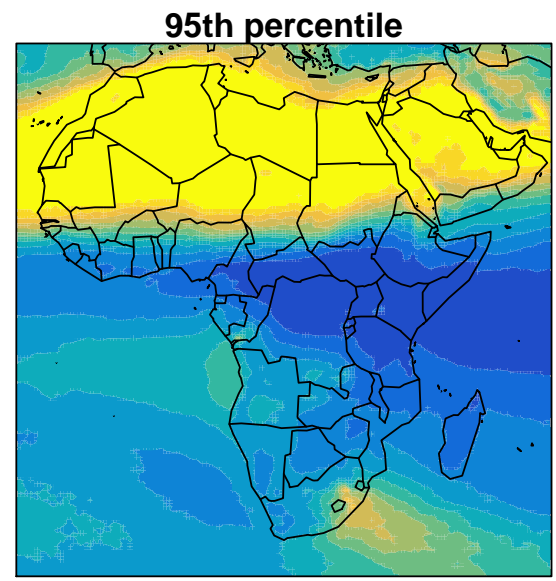

$A O D$

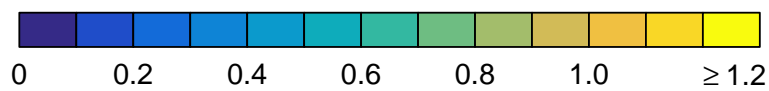

Figure 9. Seasonal variation in multiyear monthly 5th percentile, mean, and 95th percentile modeled $\mathrm{AOD}_{550 \mathrm{~nm}}$ (map background) for the full model climatology (1999-2012), with observed multiyear means (points) for all available AERONET data, for (a) September and (b) March. The number of years and range of years used for each site is the same as in Fig. 3.

spheric Africa, where aerosols are dominated by emissions that in the CMIP5 inventory are constant within a given month for a 5- to 10-year period, Fig. $9 \mathrm{~b}$ shows that finescale temporal variability can still be represented in spite of limitations in emissions inventories, consistent with previous work in this region (Myhre et al., 2003).

In March (Fig. 9a), the discrepancy in the modeled location of maximum AOD in dust-dominated northern and western Africa and the Middle East is clear, as CCAM overestimates mean AOD at all sites in this region except Djougou and Ilorin, the two southernmost sites, which are underestimated. Given that the large-scale circulation in the model is constrained to reanalysis data, it seems unlikely that issues with large-scale transport would lead to this spatial pattern in the misrepresentation of AOD. It is more likely that the overall overestimate in total dust emissions varies regionally due to regional discrepancies in precipitation, soil texture, and soil moisture, which contribute to the surface roughness (affecting surface wind speeds, feeding into the magnitude of dust emissions) and dryness (which determines the likelihood of erosion and dust emission). Dust emissions may be especially overestimated towards the north and northwest of Africa, and may even be locally underestimated in the southern Sahel. Figure 9a also shows that modeled AOD over the Arabian Peninsula is more consistent with observations, suggesting a better model representation of local dust emissions in this region (see also Sect. 4.2.3). In September, when AOD is less impacted by dust, CCAM better captures the mean AOD at the available sites in western Africa along a similar latitude band, but still significantly overes- 
timates AOD at more northern sites. This also points to a regional overestimate in dust emissions. Modeled dust lifetime, which is longer than CMIP5 and AeroCom models (see Fig. 5 and Sect. 4.1), may also play a role and could lead to dust transported too far off the northern coast of Africa. Another climate modeling study found that a non-prognostic dust scheme resulted in dust shifted too far north, while prognostic dust simulations had too much dust transport off the coast of western Africa (Mulcahy et al., 2014), suggesting the interaction between dust and meteorology in the model may be important in the current study as well. This is an area of ongoing research in CCAM.

Modeled AOD at the biomass burning source region, Mongu, is underestimated in September, as seen in Fig. 9b, but the mean modeled AOD at receptor regions like Ascension Island and Skukuza are similar to that observed. The transport in CCAM of biomass burning aerosols off the coast of Angola and southeastern Africa is visible with small enhancements in the mean modeled AOD, but is more apparent in the 5th and 95th percentile results, showing that the model captures known exit pathways for southern African biomass burning (Garstang et al., 1996; Swap et al., 2003). Figure 9b also illustrates that the transport of biomass burning aerosols from southern Africa eastward toward Réunion St. Denis is overestimated. Overall, from this analysis and given that the lifetime of $\mathrm{OC}$ and $\mathrm{BC}$ aerosols in CCAM is more consistent with other global models from AeroCom and CMIP5 (Fig. 5), biomass burning aerosol emissions and transport are relatively well represented in CCAM driven by the CMIP5 emissions inventory.

\section{Conclusions}

The compilation of long-term AERONET observations across Africa indicates different regimes of source types and their seasonality for northern, western, and southern Africa. The importance of dust and biomass burning aerosols in the regions, as well as the transport and long-range impact of these aerosol sources, are evident in the AOD and $\alpha_{\text {ext }}$ trends across sites.

The prognostic aerosol scheme in CCAM is a key feature in the coupled earth system model VRESM currently under development for inclusion in the CMIP6 intercomparison. An accurate representation of African aerosols is critical in climate models, and this current evaluation to understand how well the scheme performs in the present-day when forced with CMIP-style emissions is essential to interpreting any future climate predictions using the model. CCAM aerosol output for $\mathrm{OC}, \mathrm{BC}$, and sulfate compares well with output other CMIP5 models and AeroCom model global experiments. CCAM captures the seasonal cycle of the AOD well at most sites, with statistically significant correlation coefficients between the model and observed monthly mean time series of AOD at all but 2 of the 23 sites studied. The seasonal cycle at these sites is strongly influenced by dust and biomass burning aerosols, and thus CCAM is able to capture the general seasonal cycle of the emissions of dust and the transport of dust, carbonaceous, and sulfate aerosol types.

This analysis has also highlighted areas within CCAM and the emissions inventory that need further work. There is a notable shift in peak AOD 1 month earlier than observations in biomass burning regions. This shift has been seen in previous modeling studies, and is likely due to missing processes in the emissions inventory. Comparing to CMIP5 models and AeroCom global experiments, CCAM overestimates many dust parameters including burden and lifetime. This overestimate is also seen in the comparisons to AERONET at northern and western African sites. At the northern African sites in particular, the model has large positive normalized mean biases. The model attributes large AOD primarily to dust where the observations of the Ångström exponent and AOD suggest there is very little dust present. This is likely a combination of an overestimate of dust lifetime leading to longer-range transport of dust and higher dust burdens, and overestimated dust emissions in the northwestern Sahara. The increase in AOD in the boreal winter at western African dust-influenced sites is likely due to a high bias in ERA-Interim reanalysis wind speeds in the Sahel during this season (also present in other reanalyses). The simulation of local soil parameters and injection height in CCAM could also lead to emissions biases; testing and improvement of these fields in the CABLE land surface model in the development of VRESM may help to improve the representation of dust aerosols in Africa.

The CCAM results are consistent with state-of-the-art CMIP5 GCMs, providing confidence for using the model to study the regional impacts and linkages between African aerosols and climate change under different scenarios. In addition, CCAM can be used to downscale the CMIP5 GCMs to finer spatial scales with its variable resolution global grid, thereby refining our understanding of aerosols in this important region.

Data availability. All observational data used in this study are available for download on the AERONET website (http://aeronet. gsfc.nasa.gov). Model output is available on request from the Climate Studies, Modelling and Environmental Health Research Group at the CSIR, South Africa (Tel: + 2712841 2911, email: enquiries@csir.co.za or rgarland@csir.co.za).

Author contributions. HMH, RMG, MT, and FAE developed the research question and designed the experiment. HMH performed the analyses of AERONET and CCAM data. MT developed the prognostic aerosol scheme in CCAM. WAL provided input into the model-observation comparisons and needed statistical test. JvdM and ZD extracted and formatted CCAM data. HMH prepared the paper with input from all authors. 
Competing interests. The authors declare that they have no conflict of interest.

Acknowledgements. This work was supported by NRF CSUR grant number 9157 and a CSIR Parliamentary Grant. Hannah M. Horowitz was funded through the NSF GROW with USAID RI Fellowship. We thank the PIs and their staff for establishing and maintaining the 34 AERONET sites used in this study.

Edited by: Kostas Tsigaridis

Reviewed by: two anonymous referees

\section{References}

Abel, S. J., Highwood, E. J., Haywood, J. M., and Stringer, M. A.: The direct radiative effect of biomass burning aerosols over southern Africa, Atmos. Chem. Phys., 5, 1999-2018, https://doi.org/10.5194/acp-5-1999-2005, 2005.

AeroCom Phase II Interface: http://aerocom.met.no/cgi-bin/ aerocom/surfobs_annualrs.pl, last access: 8 September 2017.

Allen, R. J. and Landuyt, W.: The vertical distribution of black carbon in CMIP5models: Comparison to observations and the importance of convective transport, J. Geophys. Res.-Atmos., 119, 4808-4835, https://doi.org/10.1002/2014JD021595, 2014.

Anyamba, A., Justice, C. O., Tucker, C. J., and Mahoney, R.: Seasonal to interannual variability of vegetation and fires at SAFARI 2000 sites inferred from advanced very high resolution radiometer time series data, J. Geophys. Res.-Atmos., 108, D13, https://doi.org/10.1029/2002jd002464, 2003.

Archibald, S.: Managing the human component of fire regimes: lessons from Africa, Philos. T. R. Soc. B., 371, 20150346, https://doi.org/10.1098/Rstb.2015.0346, 2016.

Archibald, S., Scholes, R. J., Roy, D. P., Roberts, G., and Boschetti, L.: Southern African fire regimes as revealed by remote sensing, Int. J. Wildland Fire, 19, 861-878, https://doi.org/10.1071/WF10008, 2010.

Basart, S., Pérez, C., Cuevas, E., Baldasano, J. M., and Gobbi, G. P.: Aerosol characterization in Northern Africa, Northeastern Atlantic, Mediterranean Basin and Middle East from direct-sun AERONET observations, Atmos. Chem. Phys., 9, 8265-8282, https://doi.org/10.5194/acp-9-8265-2009, 2009.

Bond, T. C., Streets, D. G., Yarber, K. F., Nelson, S. M., Woo, J. H., and Klimont, Z.: A technology-based global inventory of black and organic carbon emissions from combustion, J. Geophys. Res.-Atmos., 109, D14203, https://doi.org/10.1029/2003jd003697, 2004.

Bond, T. C., Doherty, S. J., Fahey, D. W., Forster, P. M., Berntsen, T., DeAngelo, B. J., Flanner, M. G., Ghan, S., Karcher, B., Koch, D., Kinne, S., Kondo, Y., Quinn, P. K., Sarofim, M. C., Schultz, M. G., Schulz, M., Venkataraman, C., Zhang, H., Zhang, S., Bellouin, N., Guttikunda, S. K., Hopke, P. K., Jacobson, M. Z., Kaiser, J. W., Klimont, Z., Lohmann, U., Schwarz, J. P., Shindell, D., Storelvmo, T., Warren, S. G., and Zender, C. S.: Bounding the role of black carbon in the climate system: A scientific assessment, J. Geophys. Res.-Atmos., 118, 5380-5552, https://doi.org/10.1002/jgrd.50171, 2013.
Boucher, O., Randall, D., Artaxo, P., Bretherton, C., Feingold, G., Forster, P., Kerminen, V.-M., Kondo, Y., Liao, H., Lohmann, U., Rasch, P., Satheesh, S. K., Sherwood, S., Stevens, B., and Zhang, X.-Y.: Clouds and Aerosols, in: Climate Change 2013: The Physical Science Basis. Contribution of Working Group I to the Fifth Assessment Report of the Intergovernmental Panel on Climate Change, edited by: Stocker, T. F., Qin, D., Plattner, G.-K., Tignor, M., and Allen, S. K., Cambridge University Press, Cambridge, United Kingdom New York, NY, USA, 571-657, 2013.

Bristow, C. S., Hudson-Edwards, K. A., and Chappell, A.: Fertilizing the Amazon and equatorial Atlantic with West African dust, Geophys. Res. Lett., 37, L14807, https://doi.org/10.1029/2010gl043486, 2010.

Chiapello, I., Bergametti, G., Chatenet, B., Dulac, F., Jankowiak, I., Liousse, C., and Soares, E. S.: Contribution of the different aerosol species to the aerosol mass load and optical depth over the northeastern tropical Atlantic, J. Geophys. Res.-Atmos., 104, 2156-2202, https://doi.org/10.1029/1998JD200044, 1999.

Chin, M., Rood, R. B., Lin, S. J., Muller, J. F., and Thompson, A. M.: Atmospheric sulfur cycle simulated in the global model GOCART: Model description and global properties, J. Geophys. Res.-Atmos., 105, 24671-24687, https://doi.org/10.1029/2000jd900384, 2000.

Cooke, W. F., Koffi, B., and Gregoire, J. M.: Seasonality of vegetation fires in Africa from remote sensing data and application to a global chemistry model, J. Geophys. Res.-Atmos., 101, 2105121065, https://doi.org/10.1029/96jd01835, 1996.

Cooke, W. F., Liousse, C., Cachier, H., and Feichter, J.: Construction of a 1 degrees $\times 1$ degrees fossil fuel emission data set for carbonaceous aerosol and implementation and radiative impact in the ECHAM4 model, J. Geophys. Res.-Atmos., 104, $22137-$ 22162, https://doi.org/10.1029/1999jd900187, 1999.

Crutzen, P. J. and Andreae, M. O.: Biomass Burning in the Tropics - Impact on Atmospheric Chemistry and Biogeochemical Cycles, Science, 250, 1669-1678, https://doi.org/10.1126/Science.250.4988.1669, 1990.

Dee, D. P., Uppala, S. M., Simmons, A. J., Berrisford, P., Poli, P., Kobayashi, S., Andrae, U., Balmaseda, M. A., Balsamo, G., Bauer, P., Bechtold, P., Beljaars, A. C. M., van de Berg, L., Bidlot, J., Bormann, N., Delsol, C., Dragani, R., Fuentes, M., Geer, A. J., Haimberger, L., Healy, S. B., Hersbach, H., Hólm, E. V., Isaksen, L., Kållberg, P., Köhler, M., Matricardi, M., McNally, A. P., Monge-Sanz, B. M., Morcrette, J.-J., Park, B.-K., Peubey, C., de Rosnay, P., Tavolato, C., Thépaut, J.-N., and Vitart, F.: The ERA-Interim reanalysis: configuration and performance of the data assimilation system, Q. J. Roy. Meteorol. Soc., 137, 5535972011.

Doherty, O. M. and Evan, A. T.: Identification of a new dust-stratocumulus indirect effect over the tropical North Atlantic, Geophys. Res. Lett., 41, 6935-6942, https://doi.org/10.1002/2014GL060897, 2014.

Duncan, B. N., Martin, R. V., Staudt, A. C., Yevich, R., and Logan, J. A.: Interannual and seasonal variability of biomass burning emissions constrained by satellite observations, J. Geophys. Res.-Atmos., 108, D2, https://doi.org/10.1029/2002jd002378, 2003.

Eck, T. F., Holben, B. N., Ward, D. E., Mukelabai, M. M., Dubovik, O., Smirnov, A., Schafer, J. S., Hsu, N. C., Piketh, S. J., Queface, A., Le Roux, J., Swap, R. J., and Slutsker, I.: Variabil- 
ity of biomass burning aerosol optical characteristics in southern Africa during the SAFARI 2000 dry season campaign and a comparison of single scattering albedo estimates from radiometric measurements, J. Geophys. Res.-Atmos., 108, D13, https://doi.org/10.1029/2002jd002321, 2003.

Eck, T. F., Holben, B. N., Reid, J. S., Sinyuk, A., Dubovik, O., Smirnov, A., Giles, D., O'Neill, N. T., Tsay, S. C., and Ji, Q.: Spatial and temporal variability of column-integrated aerosol optical properties in the southern Arabian Gulf and United Arab Emirates in summer, J. Geophys. Res., 113, D01204, doi:10.1029/2007JD008944, 2008.

Edwards, D. P., Emmons, L. K., Gille, J. C., Chu, A., Attie, J. L., Giglio, L., Wood, S. W., Haywood, J., Deeter, M. N., Massie, S. T., Ziskin, D. C., and Drummond, J. R.: Satellite-observed pollution from Southern Hemisphere biomass burning, J. Geophys. Res.-Atmos., 111, D14312, https://doi.org/10.1029/2005jd006655, 2006.

Evan, A. T., Foltz, G. R., Zhang, D. X., and Vimont, D. J.: Influence of African dust on ocean-atmosphere variability in the tropical Atlantic, Nat. Geosci., 4, 762-765, https://doi.org/10.1038/NGEO1276, 2011.

Evan, A. T., Fiedler, S., Zhao, C., Menut, L., Schepanski, K., Flamant, C., and Doherty, O.: Derivation of an observation-based map of North African dust emission, Aeolian Res., 16, 153-162, https://doi.org/10.1016/j.aeolia.2015.01.001, 2015.

Evan, A. T., Flamant, C., Gaetani, M., and Guichard, F.: The past, present and future of African dust, Nature, 531, 493-495, https://doi.org/10.1038/nature17149, 2016.

Garstang, M., Tyson, P. D., Swap, R., Edwards, M., Kallberg, P., and Lindesay, J. A.: Horizontal and vertical transport of air over southern Africa, J. Geophys. Res.-Atmos., 101, 23721-23736, https://doi.org/10.1029/95jd00844, 1996.

Giglio, L., Csiszar, I., and Justice, C. O.: Global distribution and seasonality of active fires as observed with the Terra and Aqua Moderate Resolution Imaging Spectroradiometer (MODIS) sensors, J. Geophys. Res.-Biogeo., 111, G02016, https://doi.org/10.1029/2005jg000142, 2006.

Ginoux, P., Chin, M., Tegen, I., Prospero, J. M., Holben, B., Dubovik, O., and Lin, S. J.: Sources and distributions of dust aerosols simulated with the GOCART model, J. Geophys. Res.-Atmos., 106, 20255-20273, https://doi.org/10.1029/2000jd000053, 2001.

Ginoux, P., Prospero, J. M., Torres, O., and Chin, M.: Long-term simulation of global dust distribution with the GOCART model: correlation with North Atlantic Oscillation, Environ. Modell. Softw., 19, 113-128, 10.1016/S1364-8152(03)00114-2, 2004.

Guirado, C., Cuevas, E., Cachorro, V. E., Toledano, C., AlonsoPérez, S., Bustos, J. J., Basart, S., Romero, P. M., Camino, C., Mimouni, M., Zeudmi, L., Goloub, P., Baldasano, J. M., and de Frutos, A. M.: Aerosol characterization at the Saharan AERONET site Tamanrasset, Atmos. Chem. Phys., 14, 1175311773, https://doi.org/10.5194/acp-14-11753-2014, 2014.

Hamonou, E., Chazette, P., Balis, D., Dulac, F., Schneider, X., Galani, E., Ancellet, G., and Papayannis, A.: Characterization of the vertical structure of Saharan dust export to the Mediterranean basin, J. Geophys. Res.-Atmos., 104, 22257-22270, https://doi.org/10.1029/1999jd900257, 1999.

Hantson, S., Arneth, A., Harrison, S. P., Kelley, D. I., Prentice, I. C., Rabin, S. S., Archibald, S., Mouillot, F., Arnold, S. R., Artaxo,
P., Bachelet, D., Ciais, P., Forrest, M., Friedlingstein, P., Hickler, T., Kaplan, J. O., Kloster, S., Knorr, W., Lasslop, G., Li, F., Mangeon, S., Melton, J. R., Meyn, A., Sitch, S., Spessa, A., van der Werf, G. R., Voulgarakis, A., and Yue, C.: The status and challenge of global fire modelling, Biogeosciences, 13, 3359-3375, https://doi.org/10.5194/bg-13-3359-2016, 2016.

Haywood, J. M., Pelon, J., Formenti, P., Bharmal, N., Brooks, M., Capes, G., Chazette, P., Chou, C., Christopher, S., Coe, H., Cuesta, J., Derimian, Y., Desboeufs, K., Greed, G., Harrison, M., Heese, B., Highwood, E. J., Johnson, B., Mallet, M., Marticorena, B., Marsham, J., Milton, S., Myhre, G., Osborne, S. R., Parker, D. J., Rajot, J. L., Schulz, M., Slingo, A., Tanre, D., and Tulet, P.: Overview of the Dust and Biomass-burning Experiment and African Monsoon Multidisciplinary Analysis Special Observing Period-0, J. Geophys. Res.-Atmos., 113, D00C17, https://doi.org/10.1029/2008jd010077, 2008.

Holben, B. N., Eck, T. F., Slutsker, I., Tanre, D., Buis, J. P., Setzer, A., Vermote, E., Reagan, J. A., Kaufman, Y. J., Nakajima, T., Lavenu, F., Jankowiak, I., and Smirnov, A.: AERONET - A federated instrument network and data archive for aerosol characterization, Remote Sens. Environ., 66, 1-16, https://doi.org/10.1016/S0034-4257(98)00031-5, 1998.

Holben, B. N., Tanre, D., Smirnov, A., Eck, T. F., Slutsker, I., Abuhassan, N., Newcomb, W. W., Schafer, J. S., Chatenet, B., Lavenu, F., Kaufman, Y. J., Castle, J. V., Setzer, A., Markham, B., Clark, D., Frouin, R., Halthore, R., Karneli, A., O’Neill, N. T., Pietras, C., Pinker, R. T., Voss, K., and Zibordi, G.: An emerging ground-based aerosol climatology: Aerosol optical depth from AERONET, J. Geophys. Res.-Atmos., 106, 12067-12097, https://doi.org/10.1029/2001jd900014, 2001.

Huneeus, N., Schulz, M., Balkanski, Y., Griesfeller, J., Prospero, J., Kinne, S., Bauer, S., Boucher, O., Chin, M., Dentener, F., Diehl, T., Easter, R., Fillmore, D., Ghan, S., Ginoux, P., Grini, A., Horowitz, L., Koch, D., Krol, M. C., Landing, W., Liu, X., Mahowald, N., Miller, R., Morcrette, J.-J., Myhre, G., Penner, J., Perlwitz, J., Stier, P., Takemura, T., and Zender, C. S.: Global dust model intercomparison in AeroCom phase I, Atmos. Chem. Phys., 11, 7781-7816, https://doi.org/10.5194/acp11-7781-2011, 2011.

Jankowiak, I. and Tanre, D.: Satellite Climatology of Saharan Dust Outbreaks - Method and Preliminary-Results, J. Climate, 5, 646-656, https://doi.org/10.1175/15200442(1992)005<0646:Scosdo>2.0.Co;2, 1992.

Jathar, S. H., Farina, S. C., Robinson, A. L., and Adams, P. J.: The influence of semi-volatile and reactive primary emissions on the abundance and properties of global organic aerosol, Atmos. Chem. Phys., 11, 7727-7746, https://doi.org/10.5194/acp11-7727-2011, 2011.

Kinne, S., Schulz, M., Textor, C., Guibert, S., Balkanski, Y., Bauer, S. E., Berntsen, T., Berglen, T. F., Boucher, O., Chin, M., Collins, W., Dentener, F., Diehl, T., Easter, R., Feichter, J., Fillmore, D., Ghan, S., Ginoux, P., Gong, S., Grini, A., Hendricks, J., Herzog, M., Horowitz, L., Isaksen, I., Iversen, T., Kirkevåg, A., Kloster, S., Koch, D., Kristjansson, J. E., Krol, M., Lauer, A., Lamarque, J. F., Lesins, G., Liu, X., Lohmann, U., Montanaro, V., Myhre, G., Penner, J., Pitari, G., Reddy, S., Seland, O., Stier, P., Takemura, T., and Tie, X.: An AeroCom initial assessment - optical properties in aerosol component modules of global models, At- 
mos. Chem. Phys., 6, 1815-1834, https://doi.org/10.5194/acp-61815-2006, 2006.

Koch, D., Jacob, D., Tegen, I., Rind, D., and Chin, M.: Tropospheric sulfur simulation and sulfate direct radiative forcing in the Goddard Institute for Space Studies general circulation model, J. Geophys. Res.-Atmos., 104, 23799-23822, https://doi.org/10.1029/1999jd900248, 1999.

Lamarque, J.-F., Bond, T. C., Eyring, V., Granier, C., Heil, A., Klimont, Z., Lee, D., Liousse, C., Mieville, A., Owen, B., Schultz, M. G., Shindell, D., Smith, S. J., Stehfest, E., Van Aardenne, J., Cooper, O. R., Kainuma, M., Mahowald, N., McConnell, J. R., Naik, V., Riahi, K., and van Vuuren, D. P.: Historical (1850-2000) gridded anthropogenic and biomass burning emissions of reactive gases and aerosols: methodology and application, Atmos. Chem. Phys., 10, 7017-7039, https://doi.org/10.5194/acp-10-7017-2010, 2010.

Largeron, Y., Guichard, F., Bouniol, D., Couvreux, F., Kergoat, L., and Marticorena, B.: Can we use surface wind fields from meteorological reanalyses for Sahelian dust emission simulations?, Geophys. Res. Lett., 42, 2490-2499, https://doi.org/10.1002/2014GL062938, 2015.

Léon, J.-F., Derimian, Y., Chiapello, I., Tanré, D., Podvin, T., Chatenet, B., Diallo, A., and Deroo, C.: Aerosol vertical distribution and optical properties over M'Bour $\left(16.96^{\circ} \mathrm{W} ; 14.39^{\circ} \mathrm{N}\right)$, Senegal from 2006 to 2008, Atmos. Chem. Phys., 9, 9249-9261, https://doi.org/10.5194/acp-9-9249-2009, 2009.

Liousse, C., Guillaume, B., Grégoire, J. M., Mallet, M., Galy, C., Pont, V., Akpo, A., Bedou, M., Castéra, P., Dungall, L., Gardrat, E., Granier, C., Konaré, A., Malavelle, F., Mariscal, A., Mieville, A., Rosset, R., Serça, D., Solmon, F., Tummon, F., Assamoi, E., Yoboué, V., and Van Velthoven, P.: Updated African biomass burning emission inventories in the framework of the AMMAIDAF program, with an evaluation of combustion aerosols, Atmos. Chem. Phys., 10, 9631-9646, https://doi.org/10.5194/acp10-9631-2010, 2010.

Liu, X. H., Penner, J. E., and Herzog, M.: Global modeling of aerosol dynamics: Model description, evaluation, and interactions between sulfate and nonsulfate aerosols, J. Geophys. Res.Atmos., 110, D18206, https://doi.org/10.1029/2004jd005674, 2005.

Lohmann, U., Feichter, J., Chuang, C. C., and Penner, J. E.: Prediction of the number of cloud droplets in the ECHAM GCM, J. Geophys. Res.-Atmos., 104, 9169-9198, https://doi.org/10.1029/1999jd900046, 1999.

Magi, B. I., Ginoux, P., Ming, Y., and Ramaswamy, V.: Evaluation of tropical and extratropical Southern Hemisphere African aerosol properties simulated by a climate model, J. Geophys. Res.-Atmos., 114, D14204, https://doi.org/10.1029/2008jd011128, 2009.

McGregor, J. L.: C-CAM: Geometric aspects and dynamical formulation, in: CSIRO Atmospheric Research Tech. Paper No. 70, 43, 2005

Moss, R. H., Edmonds, J. A., Hibbard, K. A., Manning, M. R., Rose, S. K., van Vuuren, D. P., Carter, T. R., Emori, S., Kainuma, M., Kram, T., Meehl, G. A., Mitchell, J. F. B., Nakicenovic, N., Riahi, K., Smith, S. J., Stouffer, R. J., Thomson, A. M., Weyant, J. P., and Wilbanks, T. J.: The next generation of scenarios for climate change research and assessment, Nature, 463, 747-756, https://doi.org/10.1038/nature08823, 2010.
Moulin, C., Lambert, C. E., Dulac, F., and Dayan, U.: Control of atmospheric export of dust from North Africa by the North Atlantic oscillation, Nature, 387, 691-694, 1997.

Mulcahy, J. P., Walters, D. N., Bellouin, N., and Milton, S. F.: Impacts of increasing the aerosol complexity in the Met Office global numerical weather prediction model, Atmos. Chem. Phys., 14, 4749-4778, https://doi.org/10.5194/acp-144749-2014, 2014.

Myhre, G., Berntsen, T. K., Haywood, J. M., Sundet, J. K., Holben, B. N., Johnsrud, M., and Stordal, F.: Modeling the solar radiative impact of aerosols from biomass burning during the Southern African Regional Science Initiative (SAFARI-2000) experiment, J. Geophys. Res.-Atmos., 108, D13, https://doi.org/10.1029/2002jd002313, 2003.

Ogunjobi, K. O., He, Z., and Simmer, C.: Spectral aerosol optical properties from AERONET Sun-photometric measurements over West Africa, Atmos. Res., 88, 89-107, https://doi.org/10.1016/j.atmosres.2007.10.004, 2008.

Pace, G., di Sarra, A., Meloni, D., Piacentino, S., and Chamard, P.: Aerosol optical properties at Lampedusa (Central Mediterranean). 1. Influence of transport and identification of different aerosol types, Atmos. Chem. Phys., 6, 697-713, https://doi.org/10.5194/acp-6-697-2006, 2006.

Pinker, R. T., Liu, H., Osborne, S. R., and Akoshile, C.: Radiative effects of aerosols in sub-Sahel Africa: Dust and biomass burning, J. Geophys. Res.-Atmos., 115, D15205, https://doi.org/10.1029/2009jd013335, 2010.

Prospero, J. M., Ginoux, P., Torres, O., Nicholson, S. E., and Gill, T. E.: Environmental characterization of global sources of atmospheric soil dust identified with the Nimbus 7 Total Ozone Mapping Spectrometer (TOMS) absorbing aerosol product, Rev. Geophys., 40, 1, https://doi.org/10.1029/2000rg000095, 2002.

Putaud, J.-P., Van Dingenen, R., Mangoni, M., Virkkula, A., Raes, F., Maring, H., Prospero, J. M., Swietlicki, E., Berg, O. H., Hillamo, R., and Mäkelä, T: Chemical mass closure and assessment of the origin of the submicron aerosol in the marine boundary layer and the free troposphere at Tenerife during ACE-2, Tellus B, 52, 141-168, https://doi.org/10.1034/j.16000889.2000.00056.x, 2000.

Queface, A. J., Piketh, S. J., Eck, T. F., Tsay, S. C., and Mavume, A. F.: Climatology of aerosol optical properties in Southern Africa, Atmos. Environ., 45, 2910-2921, https://doi.org/10.1016/j.atmosenv.2011.01.056, 2011.

Querol, X., Pey, J., Pandolfi, M., Alastuey, A., Cusack, M., Perez, N., Moreno, T., Viana, M., Mihalopoulos, N., Kallos, G., and Kleanthous, S.: African dust contributions to mean ambient PM10 mass-levels across the Mediterranean Basin, Atmos. Environ., 43, 4266-4277, https://doi.org/10.1016/j.atmosenv.2009.06.013, 2009.

Rajot, J. L., Formenti, P., Alfaro, S., Desboeufs, K., Chevaillier, S., Chatenet, B., Gaudichet, A., Journet, E., Marticorena, B., Triquet, S., Maman, A., Mouget, N., and Zakou, A.: AMMA dust experiment: An overview of measurements performed during the dry season special observation period (SOP0) at the Banizoumbou (Niger) supersite, J. Geophys. Res.-Atmos., 113, D00C14, https://doi.org/10.1029/2008jd009906, 2008.

Randerson, J. T., Chen, Y., van der Werf, G. R., Rogers, B. M., and Morton, D. C.: Global burned area and biomass burning emis- 
sions from small fires, J. Geophys. Res.-Biogeo., 117, G04012, https://doi.org/10.1029/2012jg002128, 2012.

Riahi, K., Grubler, A., and Nakicenovic, N.: Scenarios of long-term socio-economic and environmental development under climate stabilization, Technol Forecast Soc, 74, 887-935, 10.1016/j.techfore.2006.05.026, 2007.

Roberts, G., Wooster, M. J., and Lagoudakis, E.: Annual and diurnal african biomass burning temporal dynamics, Biogeosciences, 6 , 849-866, https://doi.org/10.5194/bg-6-849-2009, 2009.

Rodríguez, S., Alastuey, A., Alonso-Pérez, S., Querol, X., Cuevas, E., Abreu-Afonso, J., Viana, M., Pérez, N., Pandolfi, M., and de la Rosa, J.: Transport of desert dust mixed with North African industrial pollutants in the subtropical Saharan Air Layer, Atmos. Chem. Phys., 11, 6663-6685, https://doi.org/10.5194/acp11-6663-2011, 2011.

Rotstayn, L. D. and Lohmann, U.: Simulation of the tropospheric sulfur cycle in a global model with a physically based cloud scheme, J. Geophys. Res.-Atmos., 107, D21, https://doi.org/10.1029/2002jd002128, 2002.

Rotstayn, L. D., Cai, W. J., Dix, M. R., Farquhar, G. D., Feng, Y., Ginoux, P., Herzog, M., Ito, A., Penner, J. E., Roderick, M. L., and Wang, M. H.: Have Australian rainfall and cloudiness increased due to the remote effects of Asian anthropogenic aerosols?, J. Geophys. Res.-Atmos., 112, D09202, https://doi.org/10.1029/2006jd007712, 2007.

Rotstayn, L. D., Collier, M. A., Dix, M. R., Feng, Y., Gordon, H. B., O'Farrell, S. P., Smith, I. N., and Syktus, J.: Improved simulation of Australian climate and ENSO-related rainfall variability in a global climate model with an interactive aerosol treatment, Int. J. Climatol., 30, 1067-1088, 10.1002/joc.1952, 2010.

Rotstayn, L. D., Collier, M. A., Mitchell, R. M., Qin, Y., Campbell, S. K., and Dravitzki, S. M.: Simulated enhancement of ENSO-related rainfall variability due to Australian dust, Atmos. Chem. Phys., 11, 6575-6592, https://doi.org/10.5194/acp11-6575-2011, 2011.

Rotstayn, L. D., Jeffrey, S. J., Collier, M. A., Dravitzki, S. M., Hirst, A. C., Syktus, J. I., and Wong, K. K.: Aerosoland greenhouse gas-induced changes in summer rainfall and circulation in the Australasian region: a study using singleforcing climate simulations, Atmos. Chem. Phys., 12, 63776404, https://doi.org/10.5194/acp-12-6377-2012, 2012.

Schepanski, K., Tegen, I., and Macke, A.: Saharan dust transport and deposition towards the tropical northern Atlantic, Atmos. Chem. Phys., 9, 1173-1189, https://doi.org/10.5194/acp-9-11732009, 2009.

Schütz, L., Jaenicke, R., and Petrick, H.: Saharan dust transport over the North Atlantic Ocean, GSA Special Papers, 186, 87100, https://doi.org/10.1130/SPE186-p87, 1981.

Sivakumar, V., Tesfaye, M., Alemu, W., Sharma, A., Bollig, C., and Mengistu, G.: Aerosol measurements over South Africa using LIDAR, satellite and Sun photometer, Adv. Geosci., 16, 263270, 2010.

Smirnov, A., Holben, B. N., Eck, T. F., Dubovik, O., and Slutsker, I.: Cloud-screening and quality control algorithms for the AERONET database, Remote Sens. Environ., 73, 337-349, https://doi.org/10.1016/s0034-4257(00)00109-7, 2000.

Stier, P., Schutgens, N. A. J., Bellouin, N., Bian, H., Boucher, O., Chin, M., Ghan, S., Huneeus, N., Kinne, S., Lin, G., Ma, X., Myhre, G., Penner, J. E., Randles, C. A., Samset, B., Schulz, M.,
Takemura, T., Yu, F., Yu, H., and Zhou, C.: Host model uncertainties in aerosol radiative forcing estimates: results from the AeroCom Prescribed intercomparison study, Atmos. Chem. Phys., 13, 3245-3270, https://doi.org/10.5194/acp-13-3245-2013, 2013.

Swap, R. J., Annegarn, H. J., Suttles, J. T., King, M. D., Platnick, S., Privette, J. L., and Scholes, R. J.: Africa burning: A thematic analysis of the Southern African Regional Science Initiative (SAFARI 2000), J. Geophys. Res.-Atmos., 108, D13, https://doi.org/10.1029/2003jd003747, 2003.

Tegen, I., Schepanski, K., and Heinold, B.: Comparing two years of Saharan dust source activation obtained by regional modelling and satellite observations, Atmos. Chem. Phys., 13, 2381-2390, https://doi.org/10.5194/acp-13-2381-2013, 2013.

Tesfaye, M., Sivakumar, V., Botai, J., and Tsidu, G. M.: Aerosol climatology over South Africa based on 10 years of Multiangle Imaging Spectroradiometer (MISR) data, J. Geophys. Res.Atmos., 116, D20216, https://doi.org/10.1029/2011jd016023, 2011.

Thatcher, M. and McGregor, J. L.: Using a Scale-Selective Filter for Dynamical Downscaling with the Conformal Cubic Atmospheric Model, Mon. Weather Rev., 137, 1742-1752, https://doi.org/10.1175/2008mwr2599.1, 2009.

Toledano, C., Cachorro, V. E., Berjon, A., de Frutos, A. M., Sorribas, M., de la Morena, B. A., and Goloub, P.: Aerosol optical depth and Angstrom exponent climatology at El Arenosillo AERONET site (Huelva, Spain), Q. J. Roy. Meteorol. Soc., 133, 795-807, https://doi.org/10.1002/qj.54, 2007a.

Toledano, C., Cachorro, V. E., de Frutos, A. M., Sorribas, M., Prats, N., and de la Morena, B. A.: Inventory of African desert dust events over the southwestern Iberian Peninsula in 2000-2005 with an AERONET Cimel Sun photometer, J. Geophys. Res.Atmos., 112, D21201, https://doi.org/10.1029/2006jd008307, 2007b.

Toledano, C., Cachorro, V. E., de Frutos, A. M., Torres, B., Berjon, A., Sorribas, M., and Stone, R. S.: Airmass Classification and Analysis of Aerosol Types at El Arenosillo (Spain), J. Appl. Meteor. Climatol., 48, 962-981, https://doi.org/10.1175/2008jamc2006.1, 2009.

Tsigaridis, K., Daskalakis, N., Kanakidou, M., Adams, P. J., Artaxo, P., Bahadur, R., Balkanski, Y., Bauer, S. E., Bellouin, N., Benedetti, A., Bergman, T., Berntsen, T. K., Beukes, J. P., Bian, H., Carslaw, K. S., Chin, M., Curci, G., Diehl, T., Easter, R. C., Ghan, S. J., Gong, S. L., Hodzic, A., Hoyle, C. R., Iversen, T., Jathar, S., Jimenez, J. L., Kaiser, J. W., Kirkevåg, A., Koch, D., Kokkola, H., Lee, Y. H., Lin, G., Liu, X., Luo, G., Ma, X., Mann, G. W., Mihalopoulos, N., Morcrette, J.-J., Müller, J.-F., Myhre, G., Myriokefalitakis, S., Ng, N. L., O'Donnell, D., Penner, J. E., Pozzoli, L., Pringle, K. J., Russell, L. M., Schulz, M., Sciare, J., Seland, Ø., Shindell, D. T., Sillman, S., Skeie, R. B., Spracklen, D., Stavrakou, T., Steenrod, S. D., Takemura, T., Tiitta, P., Tilmes, S., Tost, H., van Noije, T., van Zyl, P. G., von Salzen, K., Yu, F., Wang, Z., Wang, Z., Zaveri, R. A., Zhang, H., Zhang, K., Zhang, Q., and Zhang, X.: The AeroCom evaluation and intercomparison of organic aerosol in global models, Atmos. Chem. Phys., 14, 10845-10895, https://doi.org/10.5194/acp-1410845-2014, 2014.

Tummon, F., Solmon, F., Liousse, C., and Tadross, M.: Simulation of the direct and semidirect aerosol effects on the southern Africa regional climate during the biomass 
burning season, J. Geophys. Res.-Atmos., 115, D19206, https://doi.org/10.1029/2009jd013738, 2010.

Tyson, P. D., Garstang, M., and Swap, R.: Large-scale recirculation of air over southern Africa, J. Appl. Meteorol., 35, 2218-2236, https://doi.org/10.1175/15200450(1996)035<2218:Lsroao>2.0.Co;2, 1996a.

Tyson, P. D., Garstang, M., Swap, R., Kallberg, P., and Edwards, M.: An air transport climatology for subtropical southern Africa, Int. J. Climatol., 16, 265-291, 1996b.

van der Werf, G. R., Randerson, J. T., Collatz, G. J., Giglio, L., Kasibhatla, P. S., Arellano, A. F., Olsen, S. C., and Kasischke, E. S.: Continental-scale partitioning of fire emissions during the 1997 to $2001 \mathrm{El} \mathrm{Nino/La} \mathrm{Nina} \mathrm{period,} \mathrm{Science,} \mathrm{303,} \mathrm{73-76,}$ https://doi.org/10.1126/Science.1090753, 2004.

van der Werf, G. R., Randerson, J. T., Giglio, L., Collatz, G. J., Kasibhatla, P. S., and Arellano Jr., A. F.: Interannual variability in global biomass burning emissions from 1997 to 2004, Atmos. Chem. Phys., 6, 3423-3441, https://doi.org/10.5194/acp-6-34232006, 2006.

van der Werf, G. R., Randerson, J. T., Giglio, L., Collatz, G. J., Mu, M., Kasibhatla, P. S., Morton, D. C., DeFries, R. S., Jin, Y., and van Leeuwen, T. T.: Global fire emissions and the contribution of deforestation, savanna, forest, agricultural, and peat fires (1997-2009), Atmos. Chem. Phys., 10, 11707-11735, https://doi.org/10.5194/acp-10-11707-2010, 2010. van Vuuren, D. P., Edmonds, J., Kainuma, M., Riahi, K., Thomson, A., Hibbard, K., Hurtt, G. C., Kram, T., Krey, V., Lamarque, J. F., Masui, T., Meinshausen, M., Nakicenovic, N., Smith, S. J., and Rose, S. K.: The representative concentration pathways: an overview, Clim. Change, 109, 5-31, https://doi.org/10.1007/s10584-011-0148-z, 2011.

Winkler, H., Formenti, P., Esterhuyse, D. J., Swap, R. J., Helas, G., Annegarn, H. J., and Andreae, M. O.: Evidence for largescale transport of biomass burning aerosols from sunphotometry at a remote South African site, Atmos. Environ., 42, 5569-5578, https://doi.org/10.1016/j.atmosenv.2008.03.031, 2008.

Yu, H. B., Chin, M., Yuan, T. L., Bian, H. S., Remer, L. A., Prospero, J. M., Omar, A., Winker, D., Yang, Y. K., Zhang, Y., Zhang, Z. B., and Zhao, C.: The fertilizing role of African dust in the Amazon rainforest: A first multiyear assessment based on data from Cloud-Aerosol Lidar and Infrared Pathfinder Satellite Observations, Geophys. Res. Lett., 42, 1984-1991, https://doi.org/10.1002/2015GL063040, 2015.

Zender, C. S., Miller, R. L. R. L., and Tegen, I.: Quantifying mineral dust mass budgets:Terminology, constraints, and current estimates, Eos, 85, 509-512, https://doi.org/10.1029/2004EO480002, 2004.

Zuidema, P., Redemann, J., Haywood, J., Wood, R., Piketh, S., Hipondoka, M., and Formenti, P.: Smoke and Clouds above the Southeast Atlantic Upcoming Field Campaigns Probe Absorbing Aerosol's Impact on Climate, B. Am. Meteorol. Soc., 97, 11311135, https://doi.org/10.1175/bams-d-15-00082.1, 2016. 